\title{
A Study of the Impact of Soil Moisture and Surface Albedo
}

\section{Changes on Global Climate Using the MRI.GCM-I}

\author{
By Koji Yamazaki \\ Meteorological Research Institute, Tsukuba, Ibaraki 305, Japan \\ (Manuscript received 10 July 1988, in revised form 12 December 1988)
}

\begin{abstract}
The influence of changing soil moisture and surface albedo on climate is studied with an atmospheric general circulation model (MRI-GCM-I). In a control run (C run), a standard bucket model with a spatially uniform water holding capacity of $15 \mathrm{~g} \mathrm{~cm}^{-2}$ is used for the ground hydrology. The surface albedo over bare land is specified as 0.14 and that over snow-covered land varies from 0.7 to 0.85 depending on the height of the ground surface. In the second run (AW run), the surface albedo and ground wetness are specified as the climate values. In the AW run, there is no snow-albedo feedback and the ground wetness is not predicted. Two additional runs are performed for separating the effect of albedo from that of ground wetness and for examining the effect of snow albedo.

The results show that the atmospheric circulation in the Northern Hemisphere is very sensitive to the surface albedo specification in winter. In the $\mathrm{C}$ run, the Siberian high is stronger and extended southeastward compared with that in the AW run due to snow-albedo feedback in $\mathrm{C}$. The Aleutian low in the $\mathrm{C}$ run is deeper and shifts eastward. On the other hand, the Icelandic low is deeper in the $\mathrm{AW}$ run than in the $\mathrm{C}$ run.

It is found that snow albedo is an important factor which controls the northern summer climate. When snow albedo is low, snow melts earlier in spring and land becomes dry and warm in summer over the Eurasian arid region. Thus the summer precipitation is reduced there. Over the southeast Asia summer monsoon region in the model, however, moisture flux convergence is enhanced and the summer precipitation is increased. The increased precipitation makes soil wet, which in turn increases precipitation. In short, snow albedo affects summer climate significantly through the interaction of atmosphere and ground hydrological processes.

Albedo of snow-free land also has a significant effect on climate particularly in low latitudes. High/low albedo produces less/much precipitation.
\end{abstract}

\section{Introduction}

Land covers $29 \%$ of the planet earth and in the Northern Hemisphere it covers $39 \%$. The interaction between the atmosphere, the land surface and the biosphere plays an important role in forming the present climate through radiation, heat, moisture, momentum and carbon dioxide exchanges. Charney (1975) pointed out the role of surface albedo in maintaining the dryness of arid regions. He suggested a surface albedo feedback hypothesis as a plausible explanation for drought of the early seventies in Sahel. The increase in surface albedo causes the net cooling of the atmosphere and the descending motion which in turn reduces rainfall. This mechanism was tested and confirmed with the use of a GCM by Charney et al. (1977) and others (e.g., Sud and Fennessy, 1982; Sud and Smith, 1985b; Laval and Picon, 1986; Kitoh et al., 1988; Sud and Molod, 1988). Another important factor which con-

(C)1989, Meteorological Society of Japan trols climate is soil moisture. Many sensitivity experiments have been performed on it (e.g., Walker and Rowntree, 1977; Shukla and Mintz, 1982; Yeh et al., 1984; Sud and Fennessy, 1984; Sud and Smith, 1985b; Kitoh et al., 1988; Sud and Molod, 1988). The general conclusion of these experiments is that a reduced soil moisture causes a reduction in evaporation which in turn decreases rainfall. However, the impact depends on the geographical location. For instance, Sud and Smith (1985) reported little impact over India. Surface roughness is also an important factor and the sensitivity experiments were carried out by Sud and Smith (1985a, 1985b) and Sud et al. (1988).

Since Charney (1975), many GCM experiments have been made on the land surface- climate interactions. Mintz (1984) gives a comprehensive review on this subject. The MRI-GCM-I has been also used for the land surface sensitivity experiments. The influence of surface albedo and soil moisture changes on early summer climate was investigated by Yamazaki 
(1986) using the MRI-GCM-I; it showed a large impact especially in arid and semi-arid regions. The influence of soil moisture and surface albedo changes over the African tropical rain forest on summer climate was investigated by Kitoh et al. (1988).

Using a simple GCM with a limited longitudinal domain and idealized geography, the effect of largescale irrigation, i.e., initially saturated soil, on climate was investigated by Yeh et al. (1984). They showed that anomalies of soil moisture could persist for several months; the actual duration being dependent on the latitude of the initial anomaly. Wilson (1984) investigated the sensitivity of the UKMO GCM to a perturbation of surface albedo and soil moisture storage capacity over the tropical rain forests. Rind (1984) studied the influence of plants on climate by disturbing the surface albedo, the water holding capacity and the transport of water from deeper levels within the ground with the use of the GISS GCM. He removed all the vegetation over land. Each experiment was run for two years and compared with a five-years control run. The results showed the effect of surface albedo and of water holding capacity were of similar magnitude but maximized in somewhat different regions. The importance of including a full seasonal cycle in the estimation of climate change associated with vegetation removal was emphasized.

Most of the GCM studies on the land surface processes have been carried out under summer conditions; only a few GCM studies have been performed over an annual cycle. The soil moisture and snow have a much longer memory than a season. Therefore, it is possible that an atmospheric circulation anomaly in one season can affect that in the next season through soil moisture and/or snow. The famous example of such a link is the Eurasian snow cover and the Indian summer monsoon (Hahn and Shukla, 1976; Barnett et al., 1988). Thus, the land surface sensitivity experiment with a full annual cycle is worth investigating. In this paper, the influence of the surface albedo, including snow albedo, and soil moisture on climate is investigated with a seasonal cycle similar to Rind (1984) but with moderate disturbances of land processes.

The MRI-GCM-I shows many systematic biases against observations (Tokioka et al., 1985; Kitoh and Tokioka, 1986; Tokioka et al., 1986). For example, in winter, the Siberian high is too strong and shifted southeastward. In early summer, snow cover over the Eurasian continent stays longer. In summer, the precipitation over the Eurasian continent is overestimated and large even over arid regions. On the contrary, the precipitation over the central and south China is less than observed. One motivation for this study is to examine whether these model biases are related to the boundary processes of the model or not.
Section 2 describes the model and the design of the experiment. The impact of the soil moisture and surface albedo changes on the simulated climate for each season is examined in Section 3. In Section 4 , we examine the relative contribution of bare soil albedo, snow albedo and soil moisture on summer climate. Section 5 describes the annual variations of hydrological balance at selected regions. Section 6 summarizes the results with discussions.

\section{The model and the experiment}

The model used in this paper is a tropospheric version of the MRI-GCM-I. It has 5 layers in the vertical with the top at $100 \mathrm{mb}$ and has a horizontal resolution of $5^{\circ}$ in longitude and $4^{\circ}$ in latitude. Formulation of the diabatic processes includes parameterizations of cumulus convection (Arakawa and Schubert, 1974) and boundary layer processes (Randall, 1976) and a radiation calculation (Katayama, 1972). The diurnal and seasonal variations of solar insolation are taken into account. Although the cumulus parameterization has been recently modified to simulate the 30-60 day oscillation in the tropics (Tokioka et al., 1988), the original model was used in the present study.

The land surface processes in the model follows Katayama (1978) and is rather simple. The water budget is computed by Manabe's bucket model. A one-layer ground temperature prediction scheme is used. The details are as follows;

$$
\begin{aligned}
& C d T_{g} / d t=R_{S}-R_{L}-F_{S}-F_{W}+H_{i}, \\
& d W / d t=P_{r}-E-R+S_{m}, \\
& E=\beta E_{p}, \\
& \beta=\min (1.0,2 \times G W), \\
& G W=W / W_{\max } \\
& R=\left(P_{r}^{3}+D_{W}^{3}\right)^{1 / 3}-D_{W}, \\
& D_{W}=W_{\max }-W \\
& C=c h
\end{aligned}
$$

where $T_{g}$ is the ground temperature, $C$ is the bulk heat capacity of the ground, $R_{S}$ is the solar flux absorbed at the surface, $R_{L}$ is the net upward long wave flux at the surface, $F_{S}$ is the sensible heat flux, $F_{W}$ is the latent heat flux $\left(F_{W}=L \times E, L\right.$ is the latent heat of water vapor), $H_{i}$ is the snow melt and/or heat conduction through sea ice, $W$ is the available soil moisture, $P_{r}$ is the rainfall rate, $E$ is the evaporation rate, $R$ is the surface runoff, $S_{m}$ is the snowmelt, $\beta$ is the evaporation efficiency, $E_{p}$ is the potential evaporation rate, $G W$ is the ground wetness, $W_{\max }$ is the maximum available soil moisture, $D_{W}$ is the soil moisture deficiency, $c$ is the heat 
Table 1: List of experiments

\begin{tabular}{l|l|l}
\hline \hline & Albedo & Soil Moisture \\
\hline \hline C run & $\begin{array}{l}0.14 \text { overbare land } \\
0.7-0.85 \text { over snow }\end{array}$ & predicted \\
\hline AW run & Posey and Clapp & specified \\
\hline A run & Posey and Clapp & predicted \\
& & \\
\hline SA run & 0.14 overbare land & predicted \\
& $0.5-0.7$ over snow & \\
\hline \hline
\end{tabular}

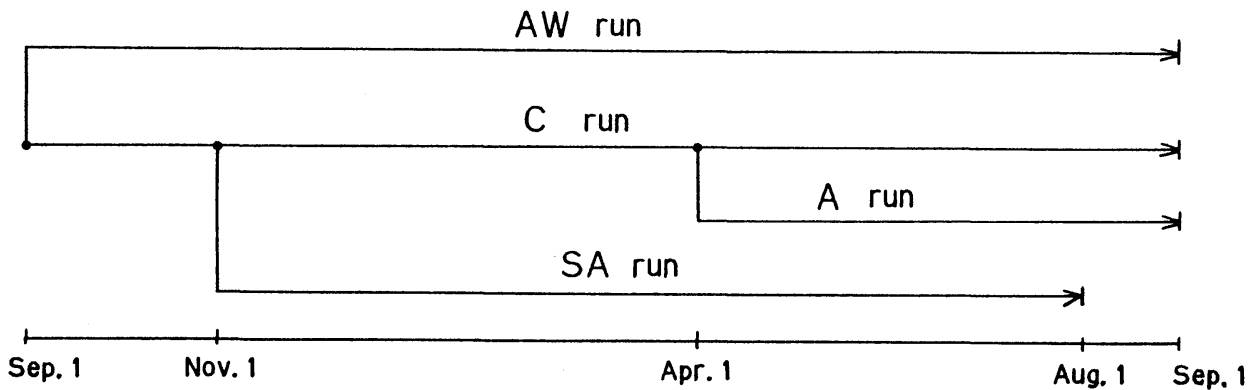

Fig. 1. Schematic illustration of experiments.

capacity of the ground surface (ice or snow or soil), and $\mathrm{h}$ is the characteristic decay depth of daily cycle of soil temperature. Here values of $W_{\max }=15$ $\mathrm{g} \mathrm{cm}^{-2}$ are adopted for all the land points. In the model, a part or all of soil moisture freezes when the ground temperature decreases below $0^{\circ} \mathrm{C}$. The bulk heat capacity, $C$, of soil depends on ground wetness and intersticial ice. Surface runoff is a function of the precipitation rate as well as the soil dryness and can occur even if the ground is not saturated when rainfall occurs.

When the surface air temperature is below $0^{\circ} \mathrm{C}$, precipitation is taken as snowfall $\left(P_{s}\right)$. The snow mass $(S)$ is a prognostic variable in the model and predicted as

$$
\partial S / \partial t=P_{s}-E(1-\delta(S))-S m,
$$

where $S$ is snow mass per unit area and $\delta()$ is as follows;

$$
\begin{aligned}
& \delta(S)=1 \text { if } S=0 \\
& \delta(S)=0 \text { if } S \neq 0 .
\end{aligned}
$$

Snowmelt $\left(S_{m}\right)$ occurs when the ground temperature is at $0^{\circ} \mathrm{C}$ and the surface surface energy balance is positive. See Tokioka et al. (1984) for further details of land surface processes in the model.

The values of surface albedo in the standard model are 0.14 for bare land, 0.07 for ocean, 0.3 for frozen land, 0.4 for bare sea ice, 0.7 for snowcovered sea ice, 0.5 for melting snow and $\min$
$(0.85,0.7+0.15 \times Z)$ for snow or ice, where $\mathrm{Z}$ is a height in $\mathrm{km}$.

The integration is made for 365 days starting from September 1. The initial atmospheric condition is taken from the September 1 condition of another experiment. The initial ground wetness is taken from the estimated climatological data (Mintz and Serafini, 1984). In the control run (here abbreviated as the $\mathrm{C}$ run), the bucket model and the surface albedo mentioned above are used.

In the albedo-wetness run (here abbreviated as the AW run), the ground wetness (GW) is prescribed according to the climatological data (Mintz and Serafini, 1984) and the surface albedo is taken from Posey and Clapp (1964; here abbreviated as $\mathrm{PC})$. In the AW run, snow-albedo feedback is not included. PC's albedo data are based on the climatological distribution of snow cover. By comparing these two runs, the impact of land surface processes (surface albedo and ground wetness) on global climate can be assessed. To separate the surface albedo impact from the ground wetness impact, an additional run (albedo-run, here abbreviated as A run), is made from the April 1 condition of the $\mathrm{C}$ run. In the $\mathrm{A}$ run, the surface albedo data by $\mathrm{PC}$ is adopted and ground wetness is predicted by the bucket model. The difference between the A run and the $\mathrm{C}$ run is the albedo specification and that between the A run and the AW run is the ground wetness prediction scheme. The fourth run (snow 
albedo run; abbreviated as SA run) is made with reduced snow albedo from November 1 of the $\mathrm{C}$ run. Table 1 and Figure 1 show the summary of the four runs. The sea surface temperature (SST) is prescribed and updated once a day according to the climatological monthly mean values for all runs.

The model used in the $\mathrm{C}$ run is basically the same as the standard MRI-GCM-I except for minor corrections. The January performance of the standard model is described by Tokioka et al. (1985) and the July performance is shown in Kitoh and Tokioka (1986). The results of a 12-year simulation with the model is presented in Tokioka et al. (1986).
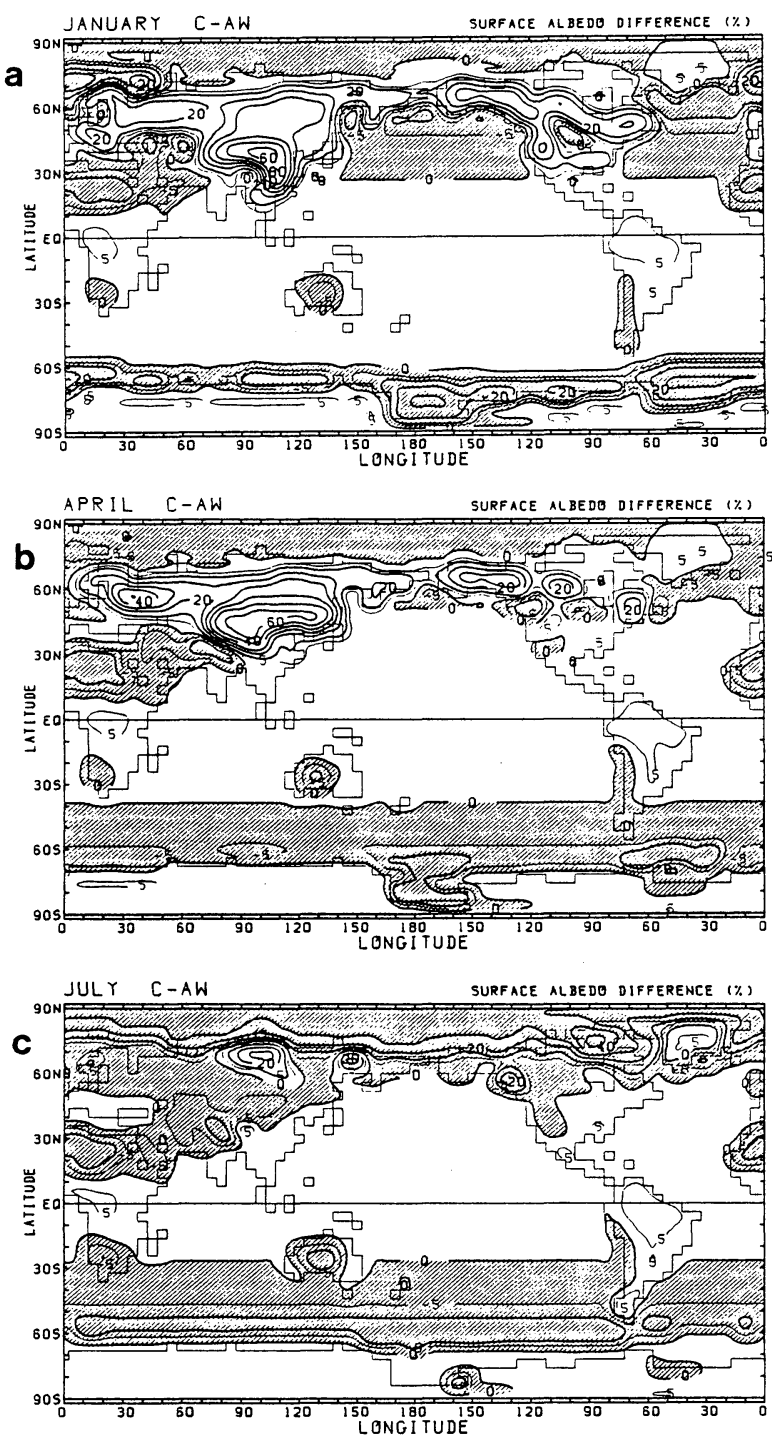

Fig. 2. Surface albedo differences between the $\mathrm{C}$ run and the AW run (C-AW) for (a) January, (b) April and (c) July. Contour interval is $10 \%$. $\pm 5 \%$ contours are added and denoted as thin lines. Negative values are shaded.

\section{Differences in the simulated climate between $C$ and AW runs}

In this section the differences in the simulated climate between the $\mathrm{C}$ run and the AW run are described for each season.

\subsection{Fall}

At the early stage of the integration, the difference in ground wetness between the $\mathrm{C}$ run and the $\mathrm{AW}$ run is small. Thus the difference in the simulated climate is mainly due to the difference in surface albedo. Over the tropical rain forest, the surface albedo in the $\mathrm{C}$ run is generally higher than that in the AW run and the opposite is true over the arid regions in the subtropics. The precipitation in the $\mathrm{C}$ run over the central Africa and Amazon (positive albedo anomaly regions) is about $1-4 \mathrm{~mm} /$ day less than that in the AW run during fall. On the other hand, a positive difference of 1-4 mm/day is simulated over Sahara and Saudi Arabia (negative albedo anomaly regions) during fall (figure not shown). These results accord with the other surface albedo sensitivity studies (e.g., Charney et al., 1977, Sud and Fennessy, 1982, Kitoh et al., 1988).

\subsection{Winter}

The surface albedo difference between the $\mathrm{C}$ run and the AW run is shown in Fig. 2. In the tropics, large differences are noted over arid regions such as the Sahara and Australia. PC's albedo (used in the AW run) over the tropical rain forest is generally smaller than the uniform value of 0.14 used in the $\mathrm{C}$ run. Since PC's surface albedo over the ocean is not constant and depends on latitudes, the difference appears even over the ocean. However, the difference is quite small over most of the ocean and it is usually less than $5 \%$. The large differences over the Eurasian continent and North America in January are caused by the different specification of snow albedo. Both in the $\mathrm{C}$ run and the $\mathrm{AW}$ run, snow covers most of the Eurasian continent and northern part of North America during winter and spring (Figs. 8 and 9). In particular, over China, where the $\mathrm{C}$ run produces snow over there but observed climatology does not, differences are greater than 0.6. During winter, snow covers most of Eurasia and Canada. Therefore the ground wetness impact is not considered to be important for the winter climate in northern middle and high latitudes.

The horizontal distribution of sea level pressure for January is shown in Fig. 3. The Siberian high in the $\mathrm{C}$ run is stronger and its southward extension is more prominent than that in the AW run. The low surface albedo in the AW run over the Asian continent prevents cooling of the surface air. The Aleutian low in the $\mathrm{C}$ run is deeper and shifted eastward and the sea level pressure over North America is low compared with that in the AW run. On 

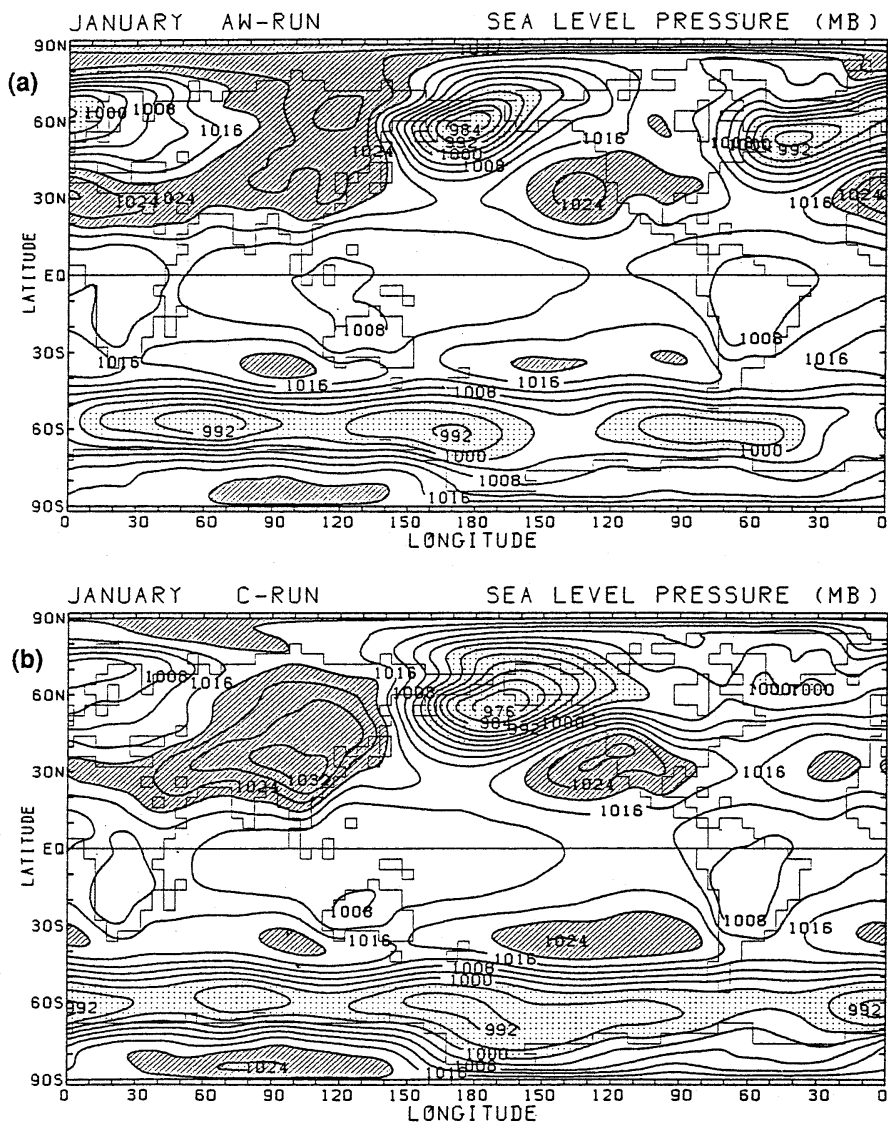

Fig. 3. Sea level pressure for the AW run (top) and the C run (bottom) for January. Contour interval is $4 \mathrm{mb}$. Values greater than $1020 \mathrm{mb}$ are hatched and those less than $1000 \mathrm{mb}$ are stippled.

the other hand, the Icelandic low in the AW run is deeper and extends to Europe. A test of statistical significance for the sea level pressure difference is shown in Appendix. It is based on the statistics of the 12-year simulation with the standard MRI.GCM-I (Tokioka et al., 1986).

Figure 4 shows the temperature difference between the $\mathrm{C}$ run and the $\mathrm{AW}$ run at $800 \mathrm{mb}$. The temperature over China in the $\mathrm{C}$ run is much colder than that in the AW run, which is consistent with a strong Siberian high in the $\mathrm{C}$ run. In the $\mathrm{C}$ run, a cold surge is strong around the Tibetan Plateau. Due to the eastward shift and intensification of the Aleutian low in the $\mathrm{C}$ run, the temperature over the Kamchatka peninsula is colder in the $\mathrm{C}$ run than that in the $\mathrm{AW}$ run. In the $\mathrm{C}$ run, the strong westerly over the North Pacific (see Fig. 3) passes the Rockies and it brings warm anomalies in temperature over North America. Warm temperatures over North America in the $\mathrm{C}$ run result in the decrease of the north-south temperature gradient and thus weaken the North Atlantic storm track activity. In the AW run, the strong southwesterly around the Icelandic low brings warm air into Europe. Thus the temperature over Europe in the AW run is warmer than that in the $\mathrm{C}$ run.

The differences (C-AW) in precipitation and ground wetness are shown in Fig. 5. The positive precipitation anomaly associated with the strong cold surge and the cyclonic activity is found over the North Pacific. The opposite is found over the North Atlantic. Over the Indian Ocean, the $\mathrm{C}$ run produces more precipitation near the equator than the AW run does. On the other hand the precipitation over the Bay of Bengal is reduced in the $\mathrm{C}$ run. These changes are consistent with the toostrong northeasterly flow at the southern periphery of the Tibetan Plateau in the $\mathrm{C}$ run.

The negative difference in ground wetness over northern Siberia is mainly caused by the difference in precipitation in September before snow covers the land (the evaporation difference is small). The difference in ground wetness there remains until spring when snow starts to melt. On the other hand, the large positive difference in ground wetness over West Asia is caused by the antecedent precipitation differences. This precipitation difference is presumably caused by the large albedo difference of bare soil there (Fig. 2). This albedo effect can be also seen over Australia. 


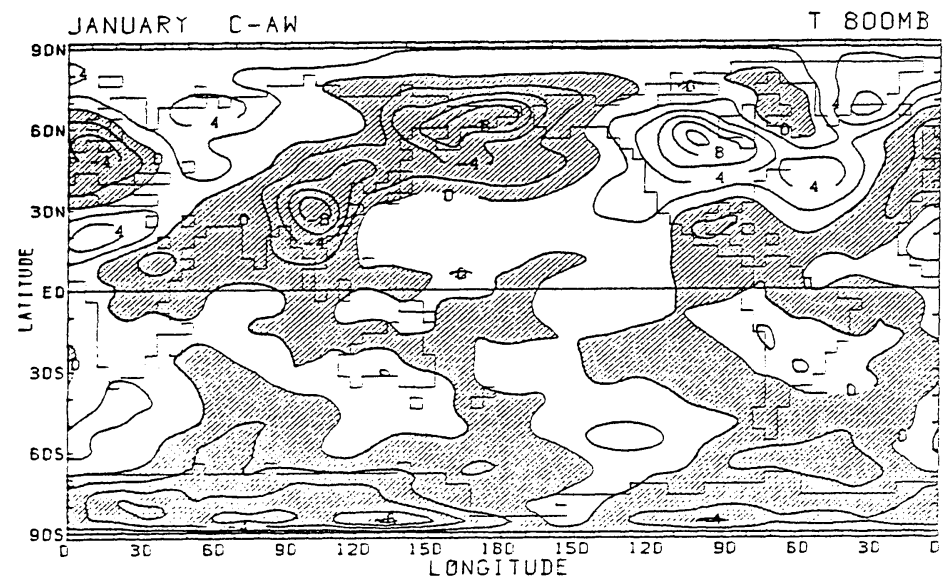

Fig. 4. Differences in temperature at $800 \mathrm{mb}$ between the $\mathrm{C}$ run and the $\mathrm{AW}$ run (C-AW) for January. Contour interval is $2 \mathrm{~K}$. Negative values are shaded.
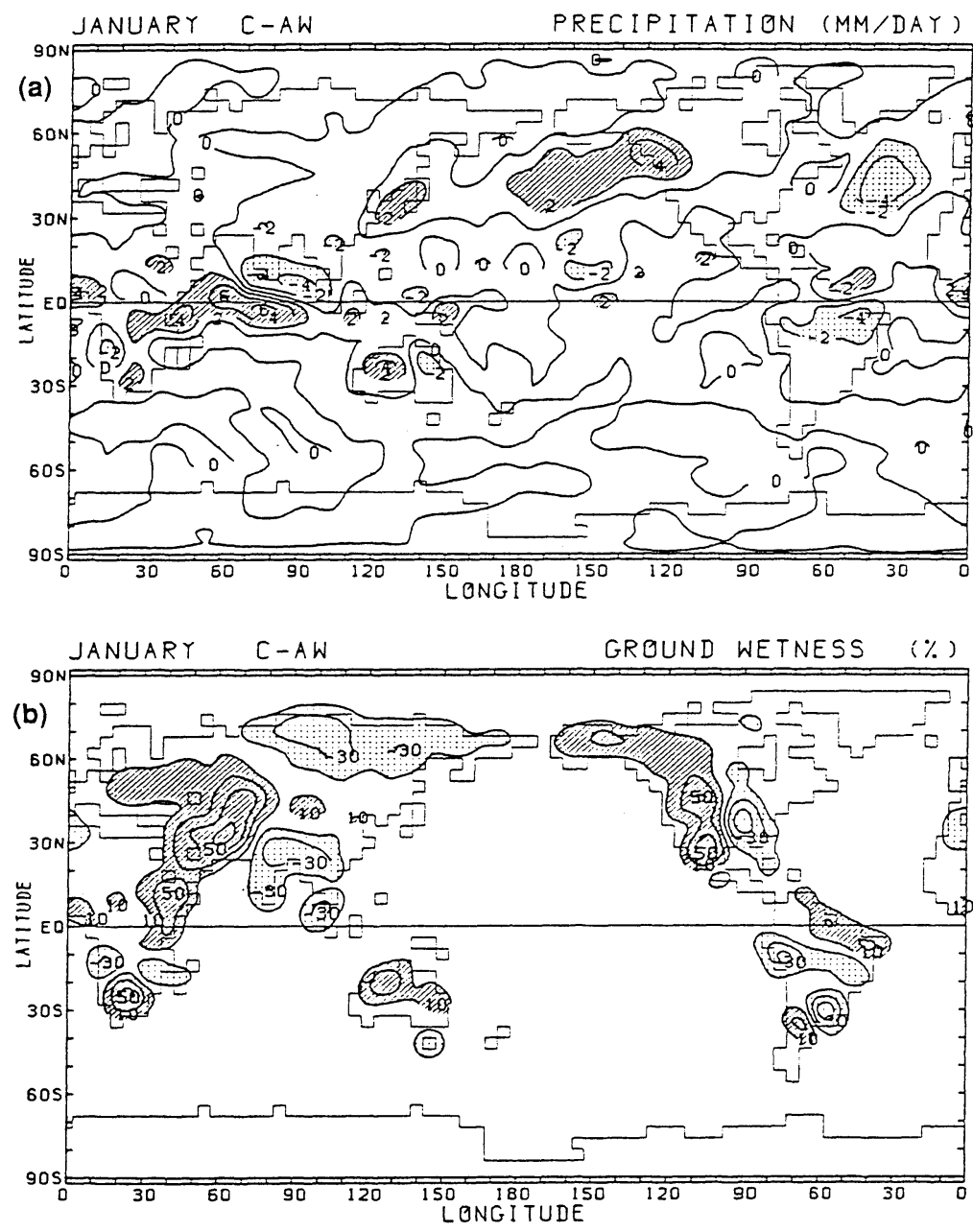

Fig. 5. Differences in (a) precipitation and (b) ground wetness between the $\mathrm{C}$ run and the AW run (C-AW) for January. Contour interval for precipitation is $2 \mathrm{~mm} /$ day. Values greater than $2 \mathrm{~mm} /$ day are hatched and those less than $-2 \mathrm{~mm} /$ day are stippled. Contour interval for ground wetness is $20 \%$. Values greater than $10 \%$ are hatched and those less than $-10 \%$ are stippled. 


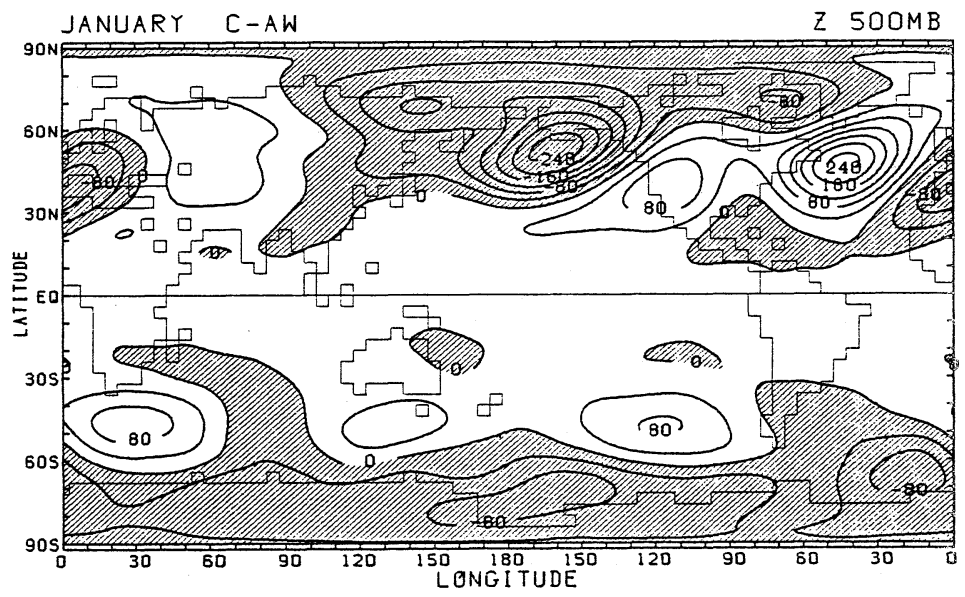

Fig. 6. Difference in geopotential height at $500 \mathrm{mb}$ between the $\mathrm{C}$ run and the $\mathrm{AW}$ run for January. Contour interval is $40 \mathrm{gpm}$. Negative values are shaded.

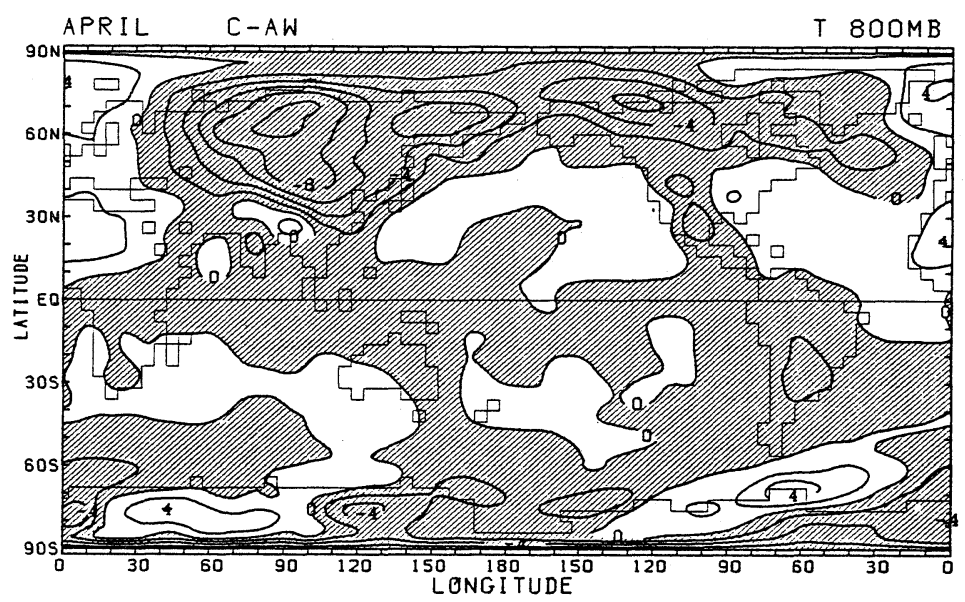

Fig. 7. Same as in Fig. 4 except for April.

The impact of the surface boundary conditions (mostly surface albedo) is not restricted near the surface. The difference in geopotential height at 500 mb shows the large impact on the large-scale circulation (Fig. 6). The large negative (positive) values are found over the North Pacific (Atlantic). These differences are in agreement with the sea level pressure difference. As expected, the westerly jet over the North Pacific in the $\mathrm{C}$ run is much stronger than in the AW run, the maximum difference of zonal wind at $200 \mathrm{mb}$ reaches $20 \mathrm{~m} / \mathrm{s}$ and the difference is about $15 \mathrm{~m} \mathrm{~s}^{-1}$ over Japan.

\subsection{Spring}

In spring, the albedo difference is very large over the continent particularly over the central Eurasia (Fig. 2b). The high surface albedo lowers the air temperature (Fig. 7). Over the Eurasia, large negative (the $\mathrm{C}$ run is colder than the $\mathrm{AW}$ run) values are noticeable. In the sea level pressure fields (figure not shown), the Siberian high still remains and its southeastward bulge also exists over the south
China in the $\mathrm{C}$ run.

Snowmelt is an important ground hydrological process during spring. Figures 8 and 9 show the seasonal variation of snow mass for the $\mathrm{C}$ run and the AW run, respectively. In winter the difference in snow cover is not so large except over China. In spring the difference between two runs becomes noticeable and the significant difference appears in May and June. Snowmelt in the AW run takes places more than one month earlier than in the $\mathrm{C}$ run. The AW simulation is closer to observations in this respect. The observed climatology of snow cover extent based on 21 years (1967-1987) NOAA/NESDIS chart is shown in Fig. 10 (Kitoh 1988; personal communication). Snow albedo specified in the $\mathrm{C}$ run $(0.70-0.85)$ is probably too high. We will discuss this point in the next section and Section 6.

\subsection{Summer}

As shown in Fig. 2c, albedo difference in July is small except over arid regions and the Arctic. The 

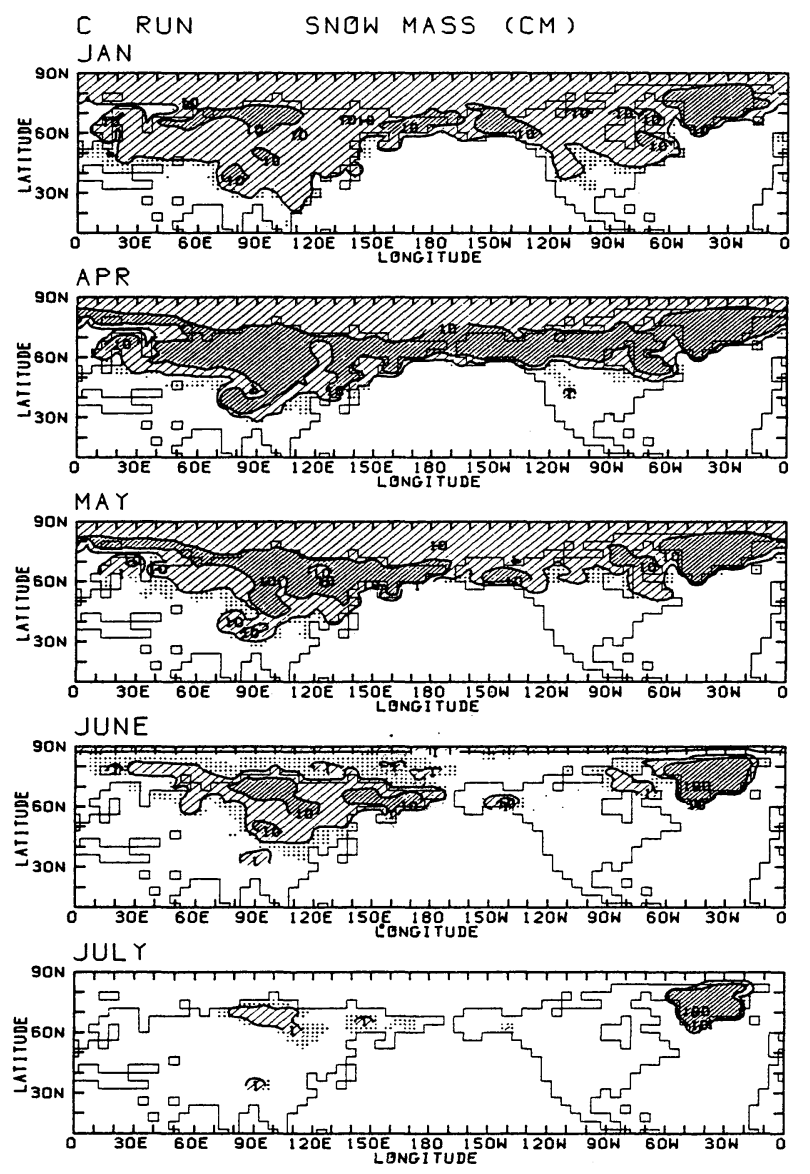

Fig. 8. Monthly mean snow mass (equivalent water content) for the $\mathrm{C}$ run. From top to bottom, January, April, May, June and July. Contours are $1 \mathrm{~cm}, 10 \mathrm{~cm}$ and 50 $\mathrm{cm}$. Values greater than $1 \mathrm{~cm}$ are hatched. Values between $0.1 \mathrm{~cm}$ and $1 \mathrm{~cm}$ are stippled.

large positive difference at north and central Siberia is caused by the existing snow in the $C$ run. Sea level pressure fields in July are shown in Fig. 11 for both runs. The difference is shown in Fig. 12. In the Arctic, the AW run gives higher pressure than the $\mathrm{C}$ run. This is presumably caused by higher albedo in the AW run. The large-scale north-south seesaw patterns, whose node lies at about $60^{\circ} \mathrm{N}$ and $60^{\circ} \mathrm{S}$, are dominant in the difference fields. Over Eurasia the sea level pressure in the $\mathrm{C}$ run is higher than that in the AW run and the low-level temperature (Fig. 13) in the $\mathrm{C}$ run is lower than that in the $\mathrm{AW}$ run. As seen in Figs. 8 and 9, the seasonal retreat of snow cover is delayed in the $\mathrm{C}$ run compared with the AW run and the ground is not heated up enough.

The differences in precipitation and ground wetness between the $\mathrm{C}$ run and the AW run are shown in Fig. 14. The large precipitation difference, greater than $4 \mathrm{~mm} /$ day, is found over the Middle East (pos-

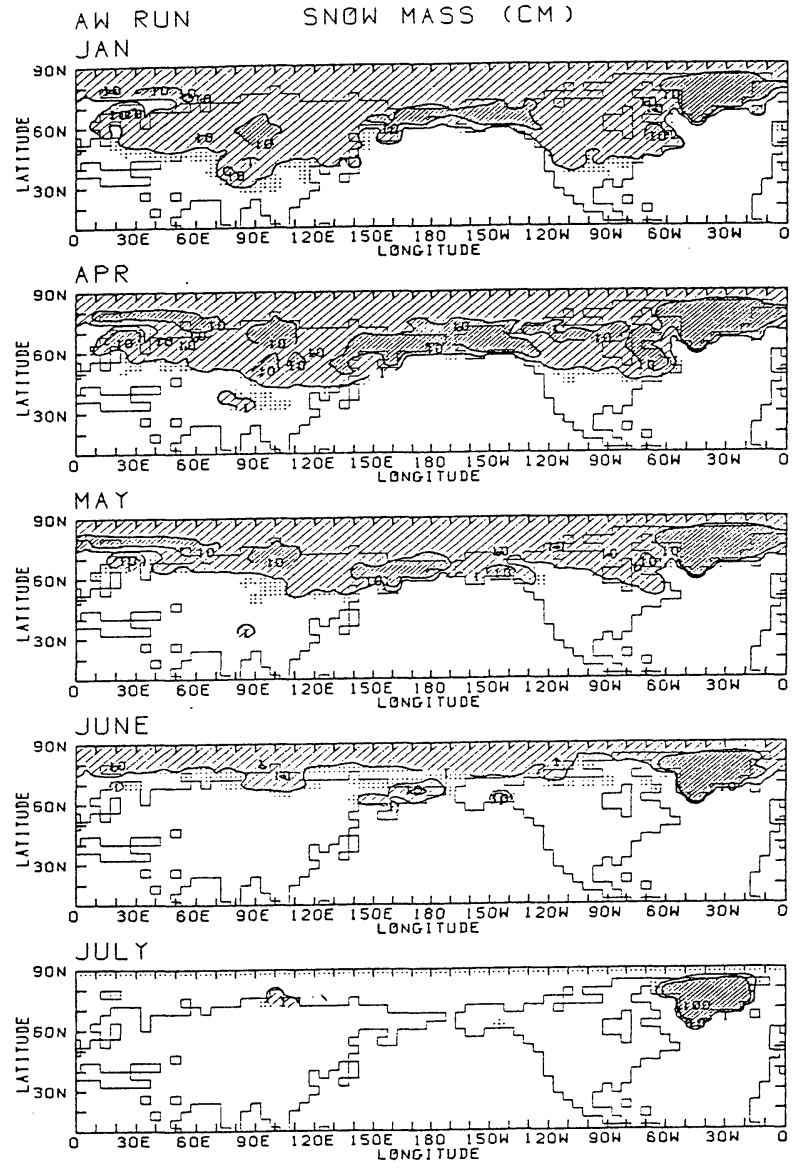

Fig. 9. Same as in Fig. 8 except for the AW run.

itive difference), over the south China (negative), over the west Africa (negative) and over the southern U.S. (negative). They are statistically significant (Fig. A2). The positive region over Eurasia forms a " $\Gamma$ " shape. This region corresponds to an arid or semi-arid region of Asia.

The change in precipitation over equatorial and north Africa in the present experiment is very similar to that in the deforestation experiment in the African tropical rain forest by Kitoh et al. (1988). In their $\mathrm{AW}$ run, the albedo between $0^{\circ} \mathrm{N}$ and $12^{\circ} \mathrm{N}$ over Africa is increased to 0.30 and the soil moisture capacity is reduced over the same region. Thus the albedo contrast between Sahara and tropical rain forest region is reduced. Therefore, AW-C in Kitoh et al. (1988) corresponds to our C-AW. Kitoh et al. (1988) and our study show that summer climate over the African tropical rain forest region and the Sahel is very sensitive to the surface boundary conditions, especially to the surface albedo.

The pattern of ground wetness difference (Fig. $14 \mathrm{~b})$ is very similar to that of precipitation difference (Fig. 14a) except over the north Siberia and Europe. One way of reasoning this high correlation is that ground wetness affects precipitation through 

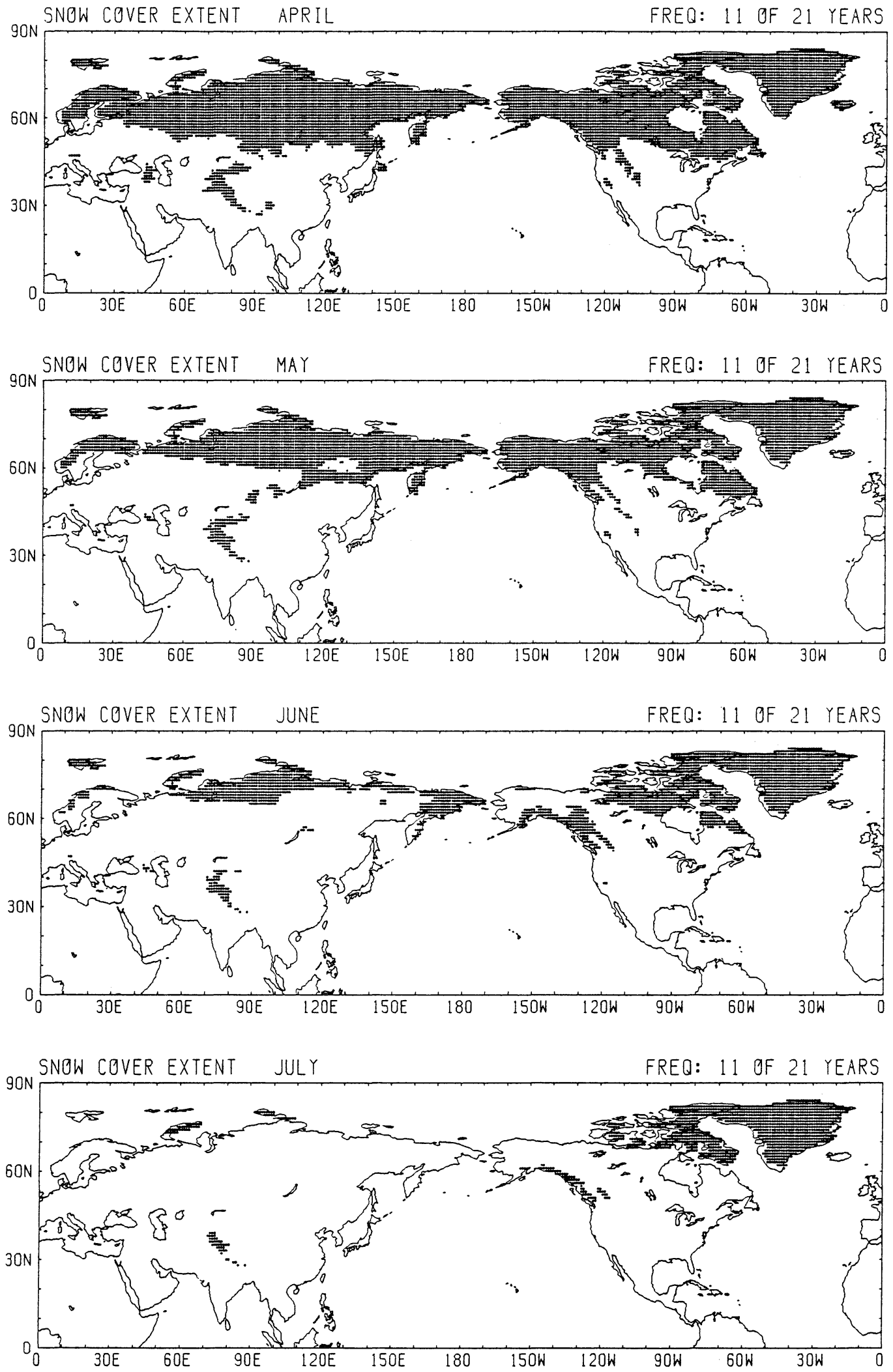

Fig. 10. Observed average snow cover extent for the period 1967-1987. Data are based on the NOAA/NESDIS snow cover chart. Stippling denotes the regions where snow exists more than 11 years among 21 years. From top to bottom, April, May, June and July. 

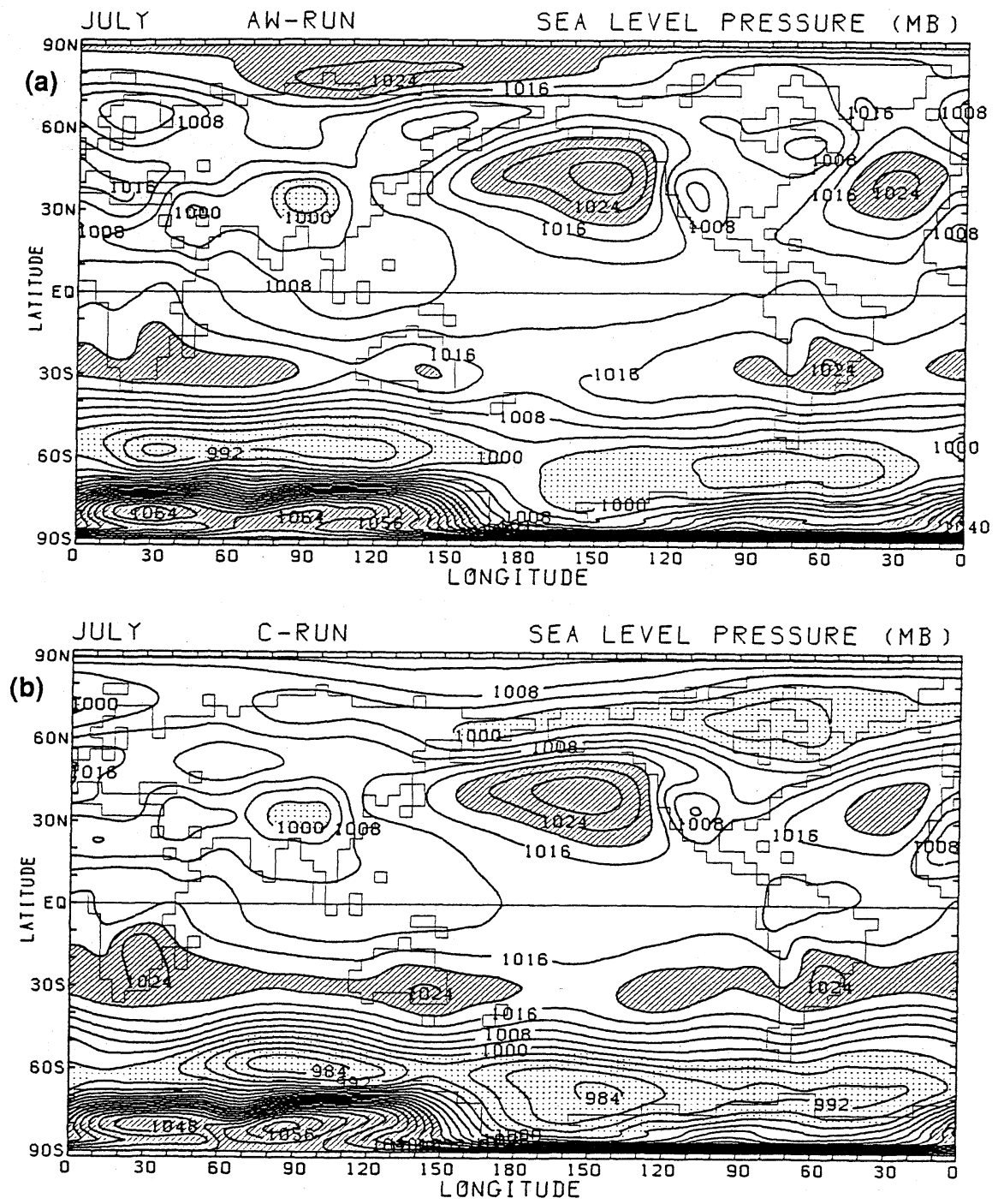

Fig. 11. Same as in Fig. 3 except for July.

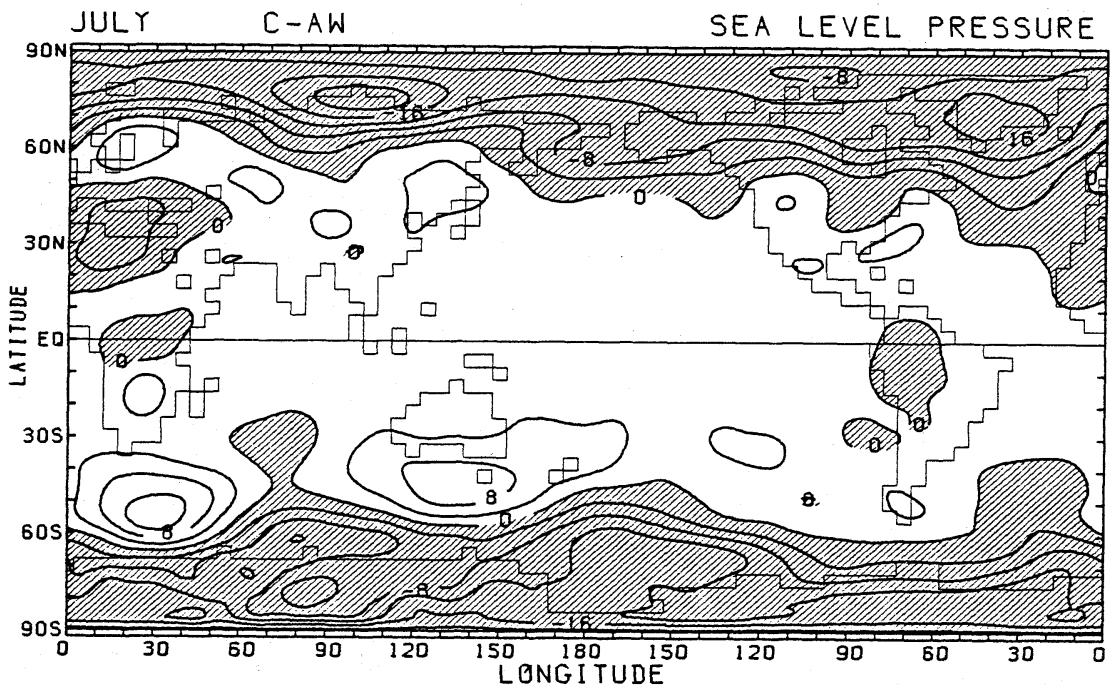

Fig. 12. Difference in sea level pressure between the $\mathrm{C}$ run and the AW run. Contour interval is $2 \mathrm{mb}$. Negative values are shaded. 


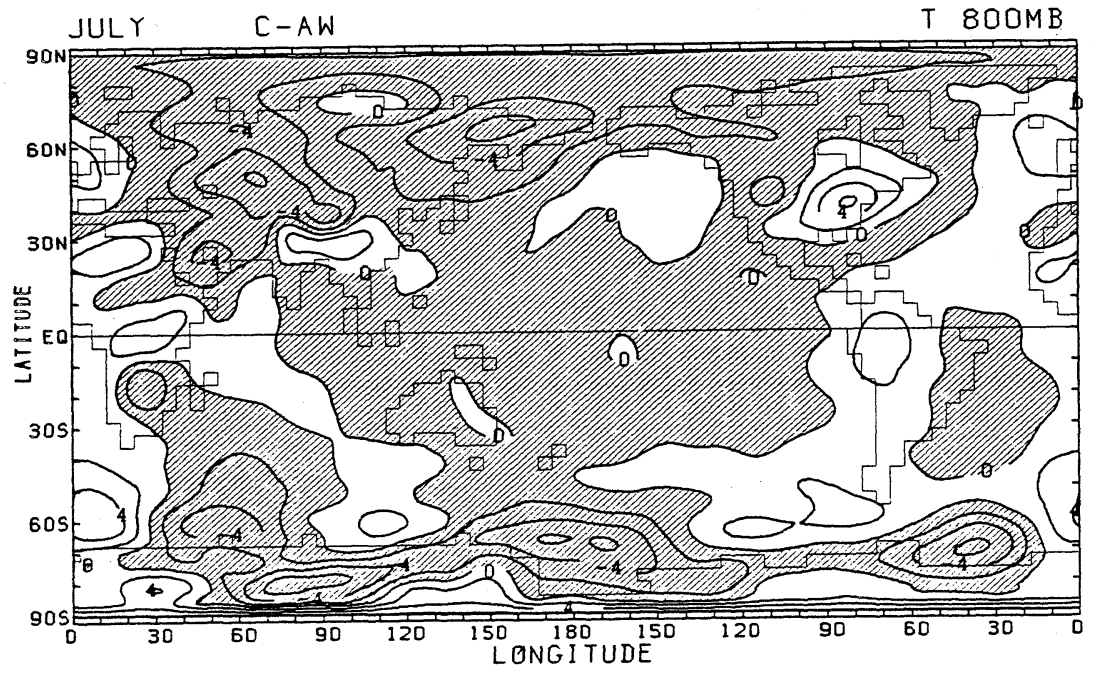

Fig. 13. Same as in Fig. 4 except for July.
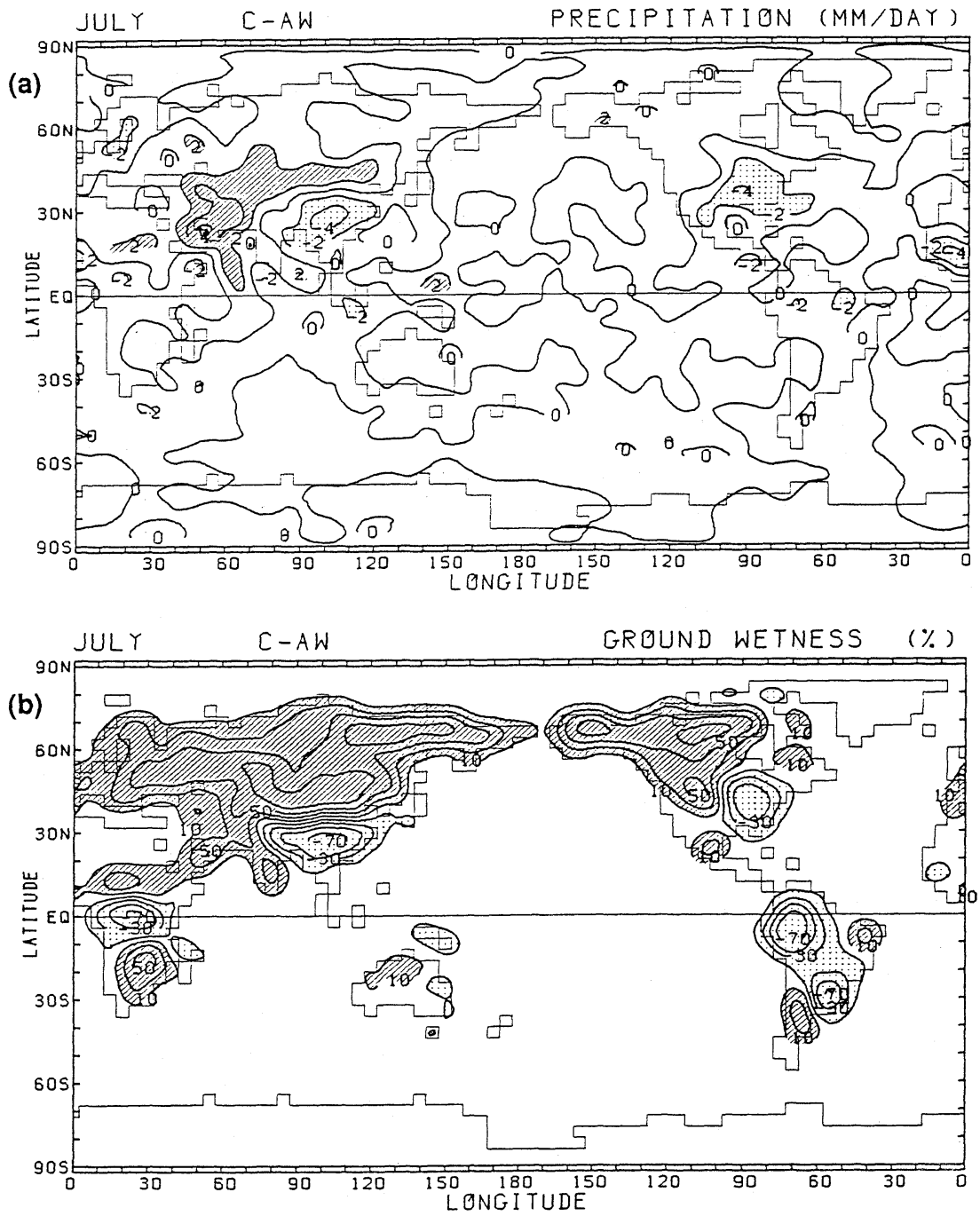

Fig. 14. Same as in Fig. 5 except for July. 


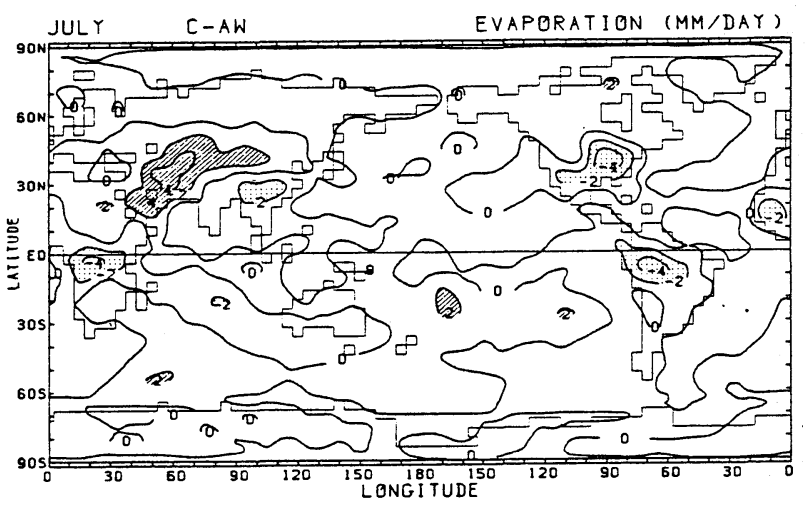

Fig. 15. Difference in evaporation between the $\mathrm{C}$ run and the AW run for July. Contour interval is $2 \mathrm{~mm} /$ day. Values greater than $2 \mathrm{~mm} /$ day are hatched. Values less than $-2 \mathrm{~mm} /$ day are stippled.

evaporation. Another way of reasoning is that affects ground wetness. For the latter process, some time lag is expected. Actually both effects exist and this positive feedback between ground wetness and precipitation enhances small change of either ground wetness or precipitation produced by some causes. This is called "ground wetness feedback" here. The difference in evaporation is shown in Fig. 15. It is very similar to the precipitation difference as expected. It may be pointed out that the evaporation ifference is more than twice as large as the precipitation difference in the tropics such as Amazon and central Africa. This suggests that the ground wetness feedback is compensated by the moisture convergence effect. On the other hand, the precipitation differences in middle-latitudes are comparable to the evaporation difference. Figure 16 shows July mean total moisture flux and its divergence field for the AW, $\mathrm{C}$ and A runs. Over the Amazon moisture flux is divergent in the AW run, while it is very weak in the $\mathrm{C}$ run. Also, over central Africa moisture flux divergence in the A run is stronger than that in the C run.

Comparing the albedo difference in Fig. 2c with the precipitation difference in Fig. 14a, we also notice a good negative correlation between them over land. In general, high surface albedo caused a decrease in ground temperature and net cooling of the atmosphere, which causes a downward motion and a reduction in precipitation. This feedback mechanism was pointed out by Charney (1975) in connection with a Sahelian drought. Here, this mechanism is called "albedo feedback". Both feedbacks seem to be working in the present experiment.
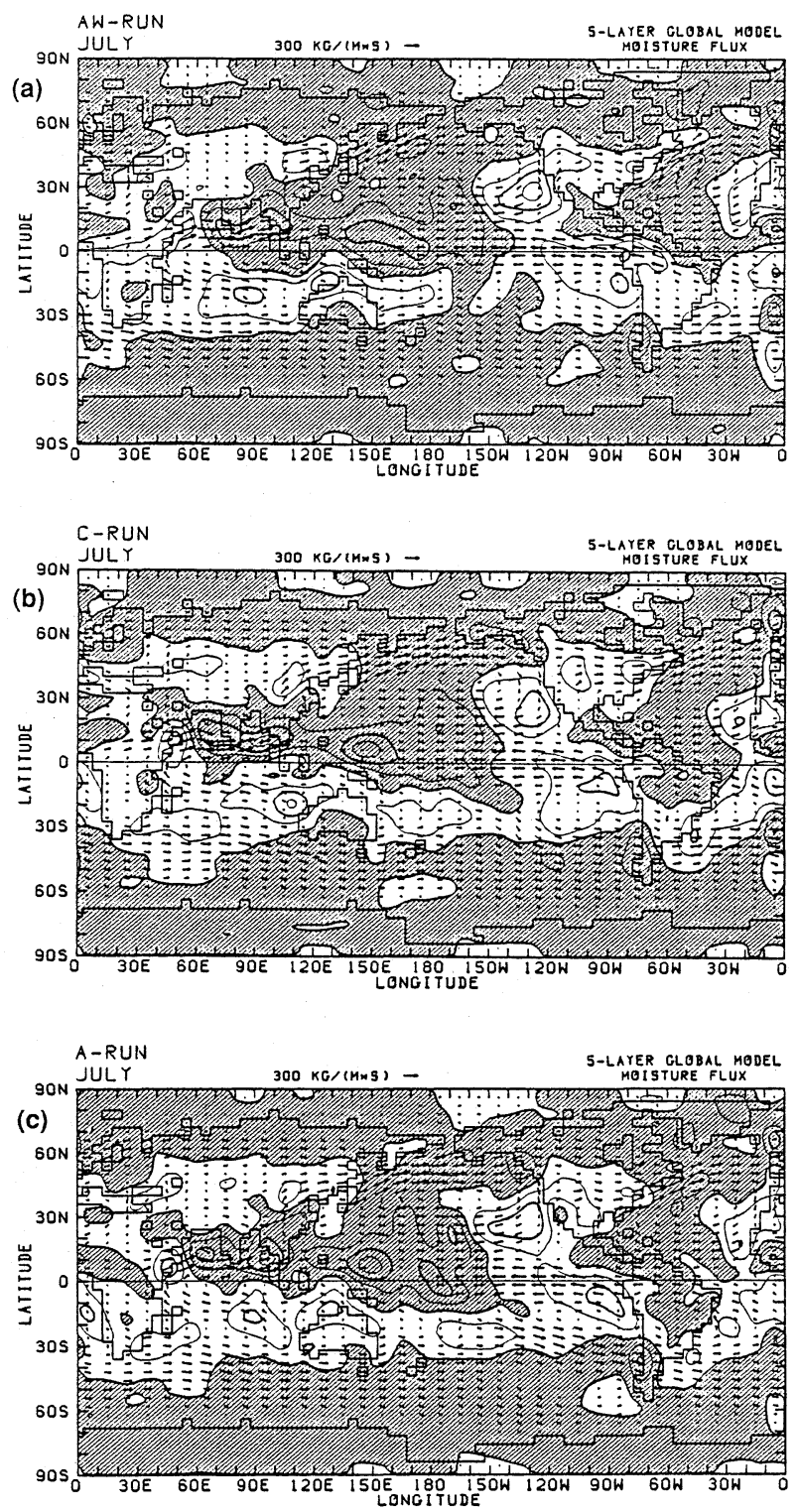

Fig. 16. July mean total moisture flux vectors and their divergence fields for the AW run (a), the $\mathrm{C}$ run (b) and the $\mathrm{A}$ run (c). The contour interval for the divergence is $2.5 \times 10^{-5} \mathrm{~kg} \mathrm{~m}^{-2} \mathrm{~s}^{-1}$. The negative (convergence) values are shaded.

The effect of the surface albedo and ground wetness changes can be seen in the flow fields in the middle troposphere. Figure 17 shows the difference in geopotential height at $500 \mathrm{mb}$ between the $\mathrm{C}$ run and the AW run. The north-south seesaw pattern is dominant in both hemispheres. Those nodes lie at about $60^{\circ} \mathrm{N}$ and $60^{\circ} \mathrm{S}$. Comparing with the sea level pressure field (Fig. 12), it is found the largescale difference is quasi-barotropic. The zonal wind speeds at $200 \mathrm{mb}$ around $60^{\circ} \mathrm{N}$ and $60^{\circ} \mathrm{S}$ are reduced in the $\mathrm{AW}$ run by as much as $10 \mathrm{~ms}^{-1}$ (figure not shown). 


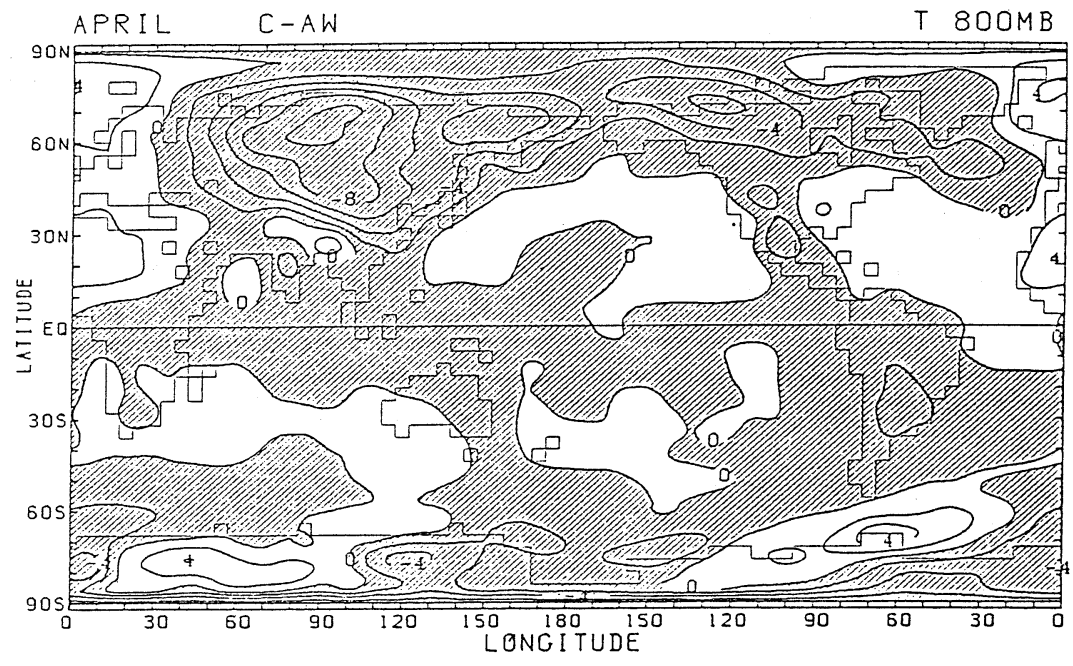

Fig. 17. Same as in Fig. 6 except for July.

\section{Surface albedo and qround wetness effects} on summer climate

In order to separate the surface albedo effect from the ground wetness effect, the third run (A run) is integrated from April 1 of the $\mathrm{C}$ run through September 1. This run uses PC's albedo and the bucket model. The initial conditions in the A run for both the atmosphere and the ground are exactly the same as in the $\mathrm{C}$ run. The only difference between the $\mathrm{A}$ run and the $\mathrm{C}$ run is in the specification of surface albedo. The difference between the $\mathrm{A}$ run and the AW run is in the initial conditions and ground wetness treatment.

The differences in precipitation and ground wetness between the $\mathrm{C}$ run and the $\mathrm{A}$ run are shown in Fig. 18. Those between the A run and the AW run are shown in Fig. 19. From these figures, it is noticed that the surface albedo effect is comparable to or slightly larger than the ground wetness effect. Note that surface albedo change causes the precipitation and snowmelt changes and thus the ground wetness change (Fig.18b). The ground wetness feedback is still working even for the difference between the $\mathrm{A}$ run and the $\mathrm{C}$ run as long as we use the bucket model. Obviously the change in surface albedo has caused the change in ground wetness in this case. The ground wetness feedback enhances the change caused by the surface albedo effect.

The large difference of surface albedo in spring between the $\mathrm{A}$ run and the $\mathrm{C}$ run is mainly due to the different treatment of snow albedo. Figure 20 shows the seasonal variation of snow mass for the $\mathrm{A}$ run. In April, the snow mass distribution in the $\mathrm{A}$ run is similar to that in the $\mathrm{C}$ run, simply because the initial conditions for the A run are taken from those in the $\mathrm{C}$ run. However, the spring retreat of snow cover in the A run is very rapid and is very close to that in the AW run (Fig. 9). When snow retreats earlier over Eurasia as in the A run, evapora- tion increases earlier and ground wetness decreases most dominantly over north China, central Asia and the Middle East (the $\Gamma$-shaped region). For ground wetness to decrease there after the snowmelt, precipitation must be less than the sum of evaporation and runoff. Because runoff is small but positive, the drying occurs when the large-scale moisture convergence does not exist or is weak. Actually, the moisture flux is mostly divergent over the $\Gamma$-shaped region during spring and summer (see, i.e., Fig. 16). On the contrary, over south China, the strong moisture convergence exists in the AW and the A runs during spring and summer.

It is suggested that snow albedo is the main cause of the difference in the continent-scale summer climate between the $\mathrm{A}$ run and the $\mathrm{C}$ run, though baresoil albedo is also different in July (Fig. 2c). To further confirm the relative importance of snow albedo and bare-soil albedo, the fourth run is conducted. In this snow albedo run (abbreviated as SA run), the snow albedo is given as $\min (0.7,0.5+0.15 \times Z)$. Thus the snow albedo in the SA run is $0.15-0.2$ less than that in the $\mathrm{C}$ run. The rest of the model in the $\mathrm{SA}$ run is the same as in the $\mathrm{C}$ run. The integration starts from 1 November and continues until the end of July. The initial conditions are taken from the $\mathrm{C}$ run. January sea level pressure in the SA run (figure not shown) does not differ much from that in the $\mathrm{C}$ run, though the southeastward bulge of the Siberian high is slightly weak in the SA run. However, the small reduction of snow albedo in the SA run increases the snowmelt quite significantly (Fig. 21). By July no snow cover exists over Eurasia and Canada in the SA run. Figure 22 shows the surface radiation and heat fluxes and snow mass averaged over northern Eurasia $\left(37.5^{\circ} \mathrm{E}-142.5^{\circ} \mathrm{E}, 52^{\circ} \mathrm{N}-\right.$ $68^{\circ} \mathrm{N}$ ) for the $\mathrm{C}$ and the SA runs. By March the snow mass in the SA run is slightly larger than that in the $\mathrm{C}$ run. During May the snow mass in the SA run rapidly decreases due to snowmelt and the 

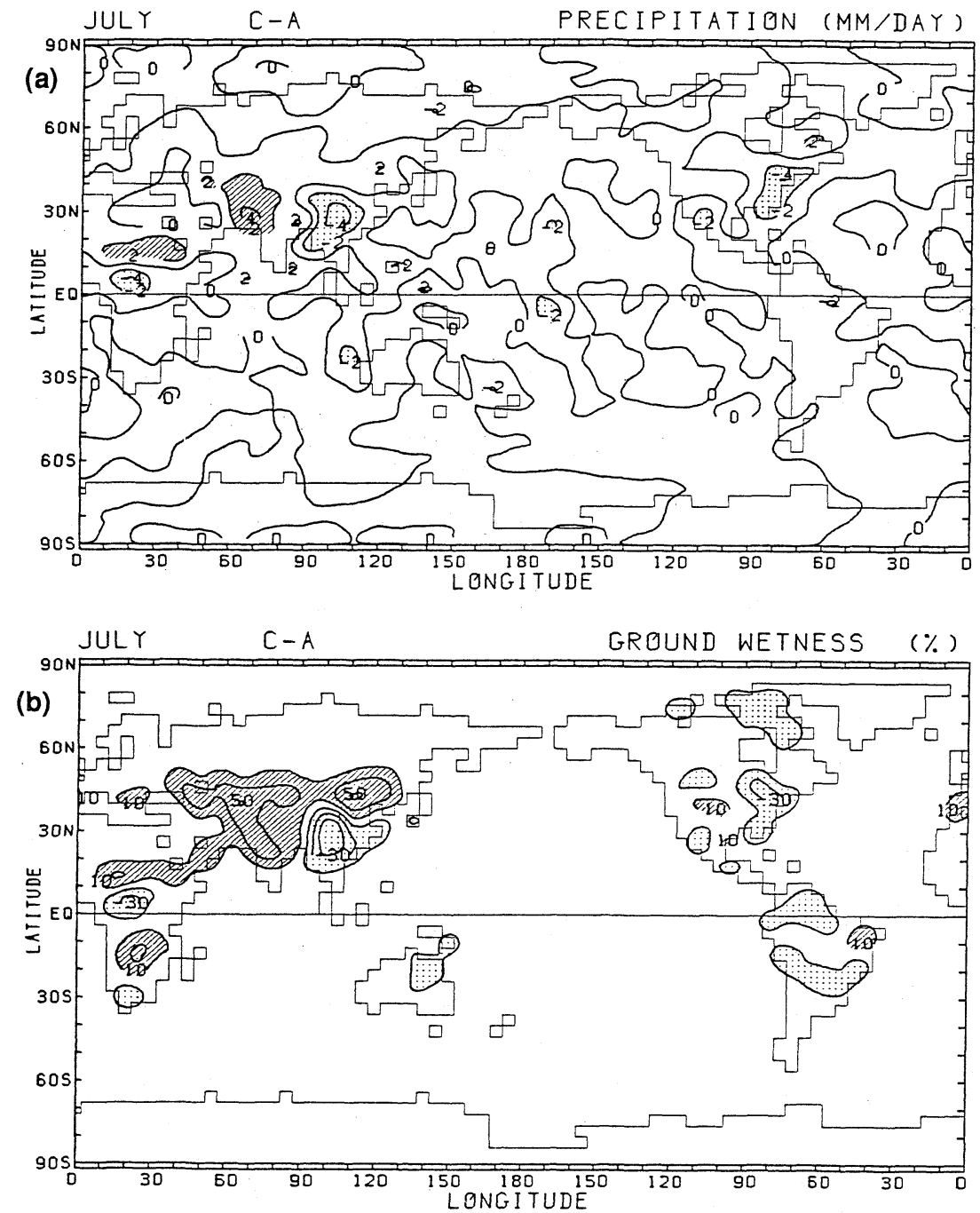

Fig. 18. Same as in Fig. 5 except for July and for between the $C$ run and the A run (C-A).

snow disappears in early June, while the decrease of snow mass in the $\mathrm{C}$ run is slow in spring. The net downward solar flux at the surface in the SA run is larger than that in the $\mathrm{C}$ run in May. This is due to the reduction of snow albedo in the SA run. The differences in June is mainly caused by the difference in snow cover extent and that in July is by the difference in cloudiness. The difference in the net long-wave radiation flux and sensible heat flux between two runs is quite small in spring. The latent heat flux in the SA run is larger than that in the $\mathrm{C}$ run, but the difference is smaller than the difference in solar radiation flux. The difference in spring snowmelt between the $\mathrm{C}$ run and SA run is caused by the direct effect of snow albedo difference.

The differences in precipitation and ground wetness between the $\mathrm{C}$ run and the SA run (Fig. 23) are similar to those between the $\mathrm{C}$ run and the $\mathrm{A}$ run (Fig. 18). Again, the $\Gamma$-shape region appears over Eurasia. This experiment demonstrates the crucial role of the snow albedo for the summer climate over
Eurasia through the ground hydrological process.

Also, the ground wetness feedback itself has a large impact on summer climate as shown in Fig. 19. However, the impact near the equator such as over the Amazon and over equatorial Africa seems to be small. For instance, over the Amazon the maximum ground wetness change is as large as $-70 \%$ but the precipitation difference is about $-1 \mathrm{~mm} /$ day. On the other hand, the surface albedo difference over the Amazon of as much as $5 \%$ produces the precipitation change of about $-1 \mathrm{~mm} /$ day. The evaporation difference over the Amazon is about -2 $\mathrm{mm}$ /day (figure not shown) which is larger than the precipitation difference. A reduced ground wetness produces a reduction in evaporation which in turn increases the ground temperature. An increase in ground temperature heats the lower atmosphere and produces a convergent lower flow, which causes a moisture flux convergence. Thus the effect of ground wetness is somewhat compensated by this dynamically induced moisture flux convergence. This neg- 

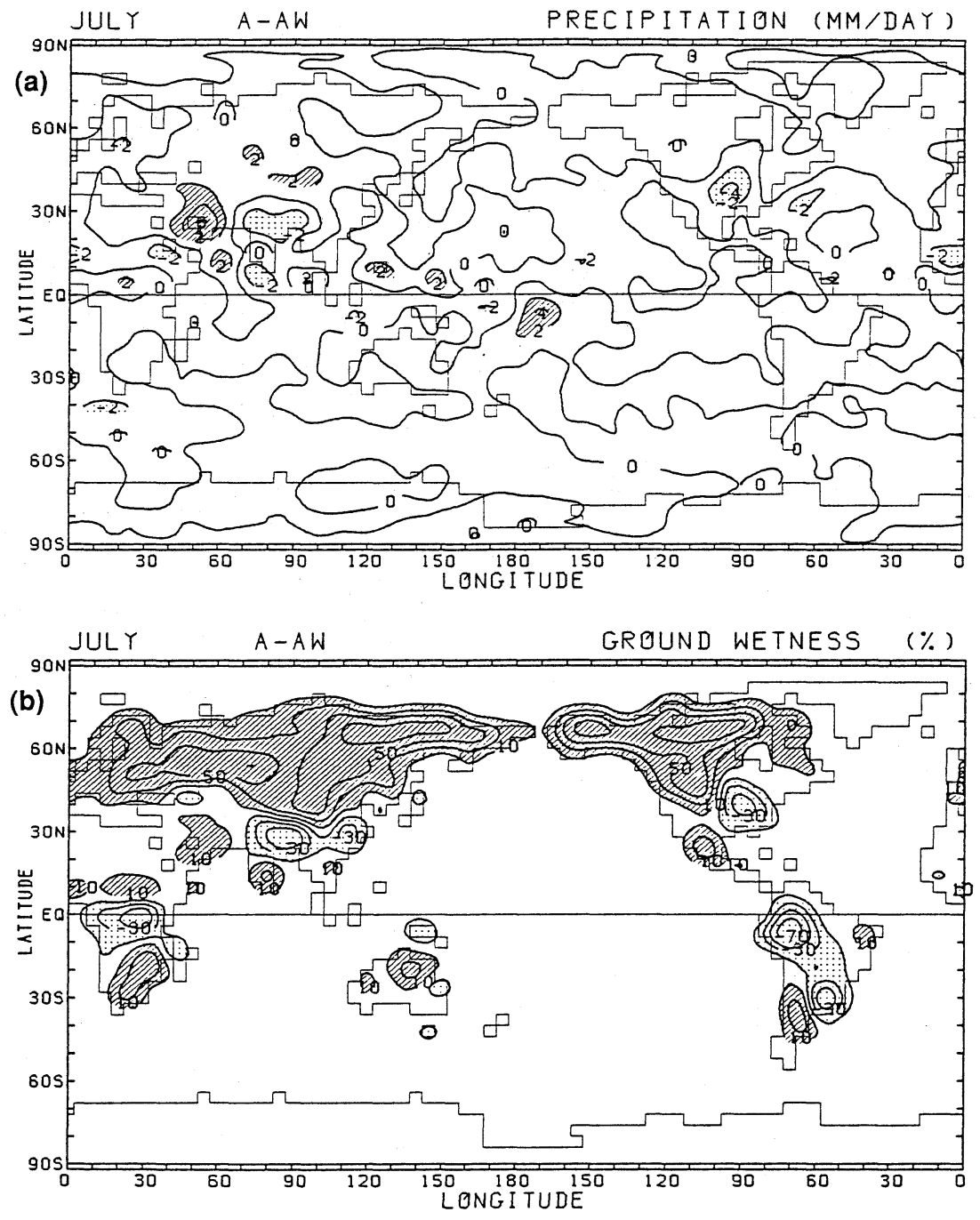

Fig. 19. Same as in Fig. 5 except for July and for between the A run and the AW run (A-AW).

ative dynamical feedback is effective over the equatorial land where moisture is abundant in the surroundings and a convergent flow can easily occur. In fact, the difference of moisture flux convergence between the A run and the AW run (Fig. 16) is large over the Amazon and equatorial Africa. This mechanism is analyzed in detail for the African deforestation experiment by Kitoh et al. (1988).

\section{Annual march of hydrological balance at selected regions}

In this section, the annual variation of hydrological balance is examined at selected regions where summer precipitation differences between the $\mathrm{C}$ run and the AW run are large.

\subsection{South China region}

Figure 24 shows monthly precipitation, evaporation, ground wetness and snow mass over the south China region $\left(97.5^{\circ} \mathrm{E}-117.5^{\circ} \mathrm{E}, 24^{\circ} \mathrm{N}-32^{\circ} \mathrm{N} ; 8\right.$ grid points). The region lies at the eastern periphery of the Tibetan plateau and does not include the coastal region. The closed circles denote observed climatological mean monthly precipitation amounts averaged over 5 stations within the region (Hankou, $30^{\circ} \mathrm{N}, 114^{\circ} \mathrm{E}$; Chengdu, $31^{\circ} \mathrm{N}, 104^{\circ} \mathrm{E}$; Changsha, $28^{\circ} \mathrm{N}, 112^{\circ} \mathrm{E}$; Kunming, $25^{\circ} \mathrm{N}, 102^{\circ} \mathrm{E}$; Chongqing, $29^{\circ} \mathrm{N}, 107^{\circ} \mathrm{E}$ ). The error bars denote the standard deviations among 5 stations.

In the $\mathrm{C}$ run (Fig. 24, middle), snow exists from November to February, which causes much colder temperature than in the AW run (Fig. 4) during winter through a snow-albedo feedback. Precipitation amounts during winter remain small in the $\mathrm{C}$ run and those are close to the observed values. Those in the AW run are larger than the observed values. In early spring, the precipitation in the $\mathrm{C}$ run increases. However, the increase in evaporation is greater than that in precipitation during spring and summer. Thus the ground wetness keeps decreasing and it becomes below $50 \%$ in May. As a consequence, the summer precipitation in the $\mathrm{C}$ run 


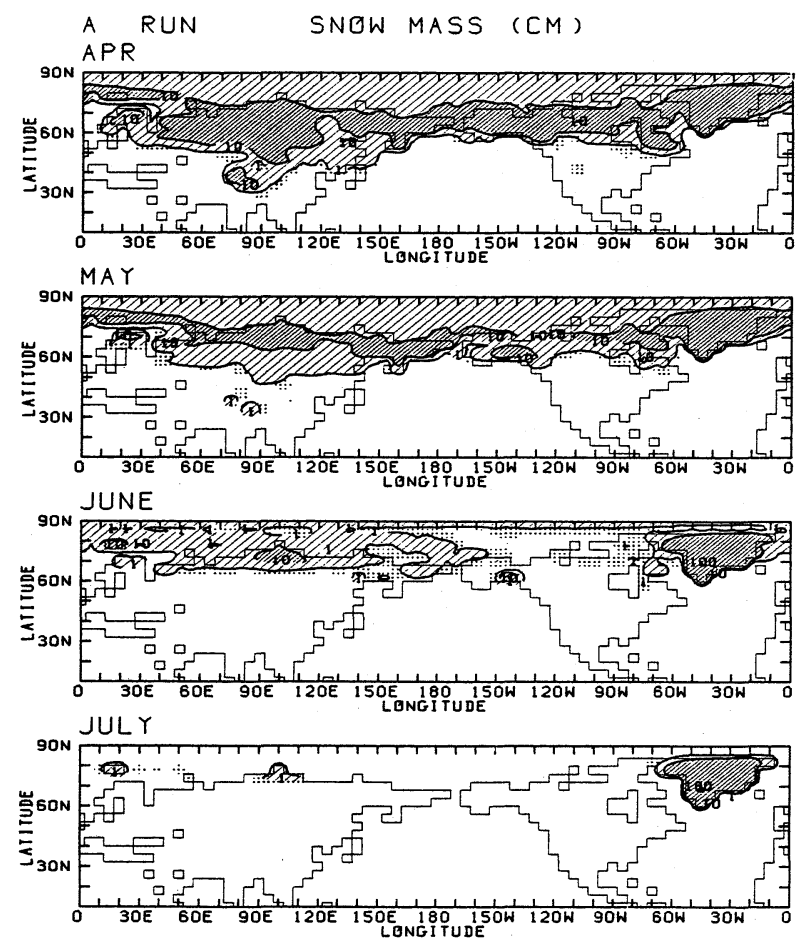

Fig. 20. Same as in Fig. 8 except for the A run. January is not included.

is much less than that in the AW run or observed. On the other hand, the precipitation in the AW run is excessive in spring and that is close to the observed values during summer. The specified ground wetness in the AW run does not have a large annual variation and stays above $50 \%$.

The large difference in spring comes from the large albedo difference around the region (see Fig. 2b). In April, the surface albedo in the $C$ run is much larger than that in the AW run over the central Eurasia where snow remains. In summer both precipitation and evaporation in the $\mathrm{C}$ run are about 100 $\mathrm{mm} / \mathrm{month}$, while those in the AW run are about $200 \mathrm{~mm} / \mathrm{month}$. The difference of "precipitation minus evaporation (P-E)" between the AW run and the $\mathrm{C}$ run is small compared with the difference of precipitation or evaporation between two runs. This suggests that the large difference between two runs in July is accounted for mainly by the difference in ground wetness. As shown in Equation (4), evaporation efficiency is 1 when ground wetness is above $50 \%$, while it decreases with the decrease in ground wetness. Albedo difference in July is less than $5 \%$ at this region (see Fig. 2c). Therefore, the difference in ground wetness is the main cause for the large precipitation difference in summer.

Looking at the results in the A run, it is demonstrated that the dry ground wetness in summer is caused by the surface albedo difference. In April, the precipitation in the $A$ run is above that in the $C$
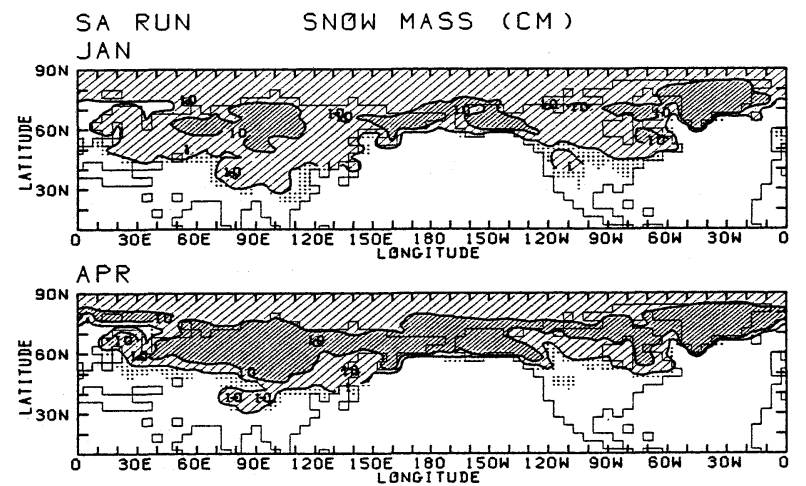
MAY
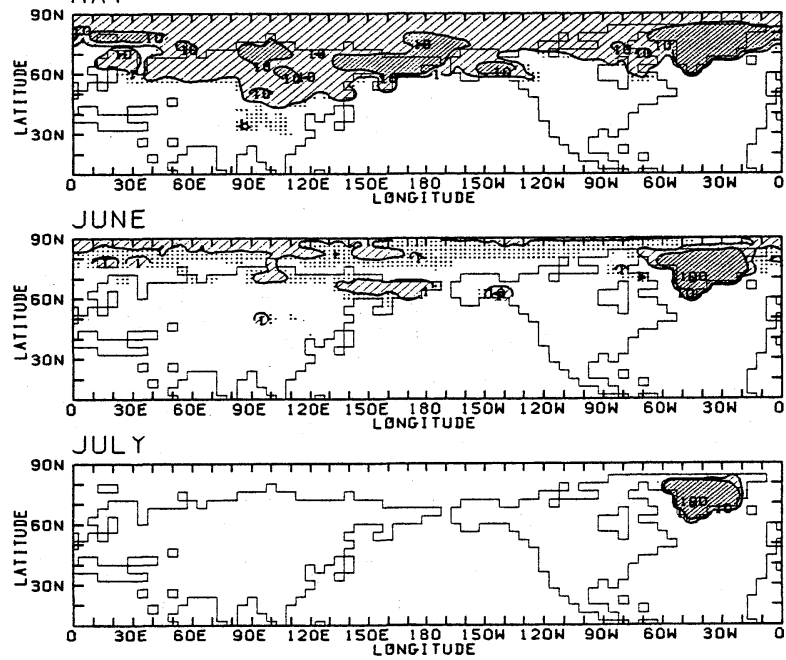

Fig. 21. Same as in Fig. 8 except for the SA run.

run and below that in the AW run. In May, the precipitation in the A run is close to that in the AW run and ground wetness in the A run turns to increase after May and it keeps increasing during summer. The ground wetness in the A run is above $50 \%$ during summer. The surface albedo in spring plays a crucial role for summer climate in this region.

In the $\mathrm{C}$ run, the ground wetness at the end of integration (August) is very dry and it is expected to remain dry in next fall and winter. Thus if the model continues to be integrated to next summer, the precipitation in next spring and summer will be less than that in the previous year and large deviation from actural observations will be obtained. Several-year integration will be needed to obtain the recursive annual variation in the model with an interactive ground moisture scheme.

\subsection{Gobi Desert region}

Figure 25 shows monthly precipitation, evaporation, ground wetness and snow mass over the Gobi Desert region $\left(87.5^{\circ} \mathrm{E}-107.5^{\circ} \mathrm{E}, 40^{\circ} \mathrm{N}-48^{\circ} \mathrm{N} ; 8\right.$ grid points) together with observed precipitation climatology at Ulan Bator $\left(48^{\circ} \mathrm{N}, 107^{\circ} \mathrm{E}\right.$, denoted by closed circles) and Urumqi $\left(44^{\circ} \mathrm{N}, 88^{\circ} \mathrm{E}\right.$, denoted by crosses). The region is arid or semi-arid.

In the $\mathrm{C}$ run, large snow mass is predicted during 
winter and snow stays until June. The ground wetness in June is well above $50 \%$ and it decreases after snowmelt but still above $50 \%$ even in August. The precipitation in the following fall will be excessive. A large precipitation amount is produced after the snowmelt, i.e., in July and August. The results in the $\mathrm{C}$ run are unrealistic for the Gobi Desert region, though the observation points are only two. In the AW run, summer precipitation is much reduced and accordance with observation is better, though the precipitation in winter is excessive. In the A run, snow rapidly disappears around May and ground wetness starts decreasing but is still large even in August. Hence the summer precipitation is much
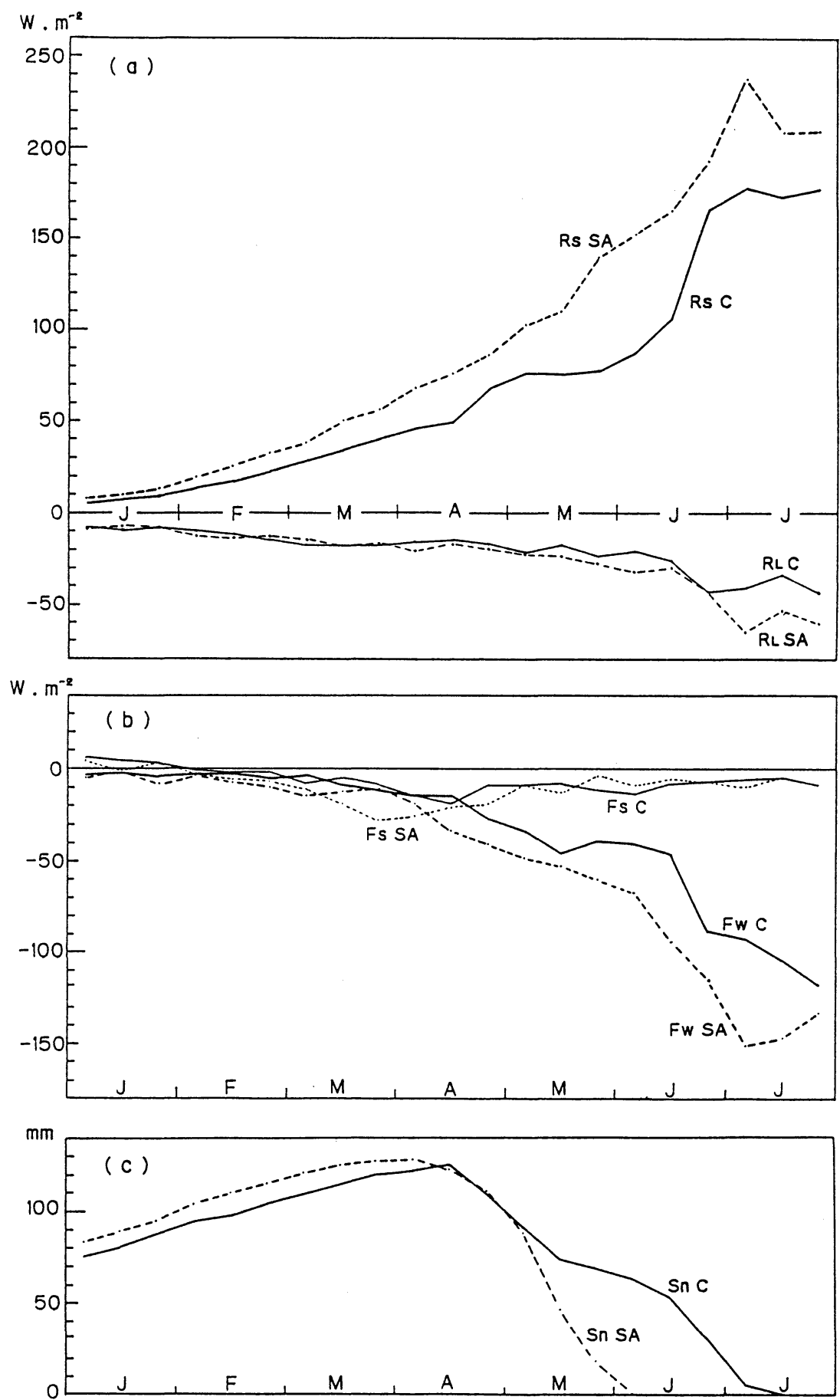

Fig. 22. (a) Time variation of net downward solar radiation flux at the surface $\left(R_{S}\right)$ and net downward longwave radiation flux at the surface $\left(R_{L}\right)$ averaged over northern Eurasia $\left(37.5^{\circ} \mathrm{E}-142.5^{\circ} \mathrm{E}, 52^{\circ} \mathrm{N}-\right.$ $68^{\circ} \mathrm{N}$ ) for the $\mathrm{C}$ run (solid line) and the SA run (dashed line). The abscissa is time; from January through July. (b) Same as in (a) but for downward sensible heat flux at the surface $\left(F_{S}\right)$ and downward latent heat flux at the surface $\left(F_{W}\right)$. (c) Same as in (a) but for snow mass. 
larger than that in the AW run. Over this region, moisture flux is divergent for all the runs as shown in Fig. 16. Therefore the precipitation can not be larger than the evaporation. Thus the small evaporation in the AW run produces the small precipitation in the AW run. Probably the specified field capacity of $15 \mathrm{~g} \mathrm{~cm}^{-2}$ in the $\mathrm{C}$ run and the $A$ run is too large for this region because this region is very arid and vegetation is sparse.

The winter precipitation amount is excessive both in the AW run and the $\mathrm{C}$ run. This deficiency does not seem to be related to the surface albedo. One possible reason for this is too small a surface drag of the model over land in winter conditions. With the smooth land surface, the cyclone activity over the Eurasia is less damped. Thus the precipitation associated with the cyclone activity over the Eurasia increases. The effect of increased surface drag coefficient over the continents under winter conditions is studied with the MRI.GCM by Yagai and Tokioka (1987). When the surface drag is enhanced according to the subgrid-scale topography, the precipita- tion over the central Asia reduces by $1-2 \mathrm{~mm} /$ day (their Fig. 8). These values are quite large compared with the simulated average precipitation of 1-3 mm/day there (Tokioka et al., 1985).

\subsection{Central U.S. region}

Figure 26 shows monthly precipitation, evaporation, ground wetness and snow mass over the central U.S. region $\left(77.5^{\circ} \mathrm{W}-92.5^{\circ} \mathrm{W}, 36^{\circ} \mathrm{N}-48^{\circ} \mathrm{N} ; 9\right.$ grid points). The closed circles denote observed climatological mean monthly precipitation amounts averaged over 7 stations within the region (Saint Louis, $39^{\circ} \mathrm{N}, 90^{\circ} \mathrm{W}$; Duluth, $47^{\circ} \mathrm{N}, 92^{\circ} \mathrm{W}$; Chicago, $42^{\circ} \mathrm{N}$, $88^{\circ} \mathrm{W}$; Columbus, $40^{\circ} \mathrm{N}, 83^{\circ} \mathrm{W}$; Saultn Ste Marie, $46^{\circ} \mathrm{N}, 80^{\circ} \mathrm{W}$; Toronto, $44^{\circ} \mathrm{N}, 80^{\circ} \mathrm{W}$; Nashville, $36^{\circ} \mathrm{N}$, $\left.87^{\circ} \mathrm{W}\right)$. The error bars denote the standard deviations among 7 stations.

During winter, the differences between the AW run and the $\mathrm{C}$ run are not large and both runs do not differ from observations. In summer, differences of precipitation, ground wetness and surface albedo between the $\mathrm{C}$ run and the $\mathrm{AW}$ run are similar to
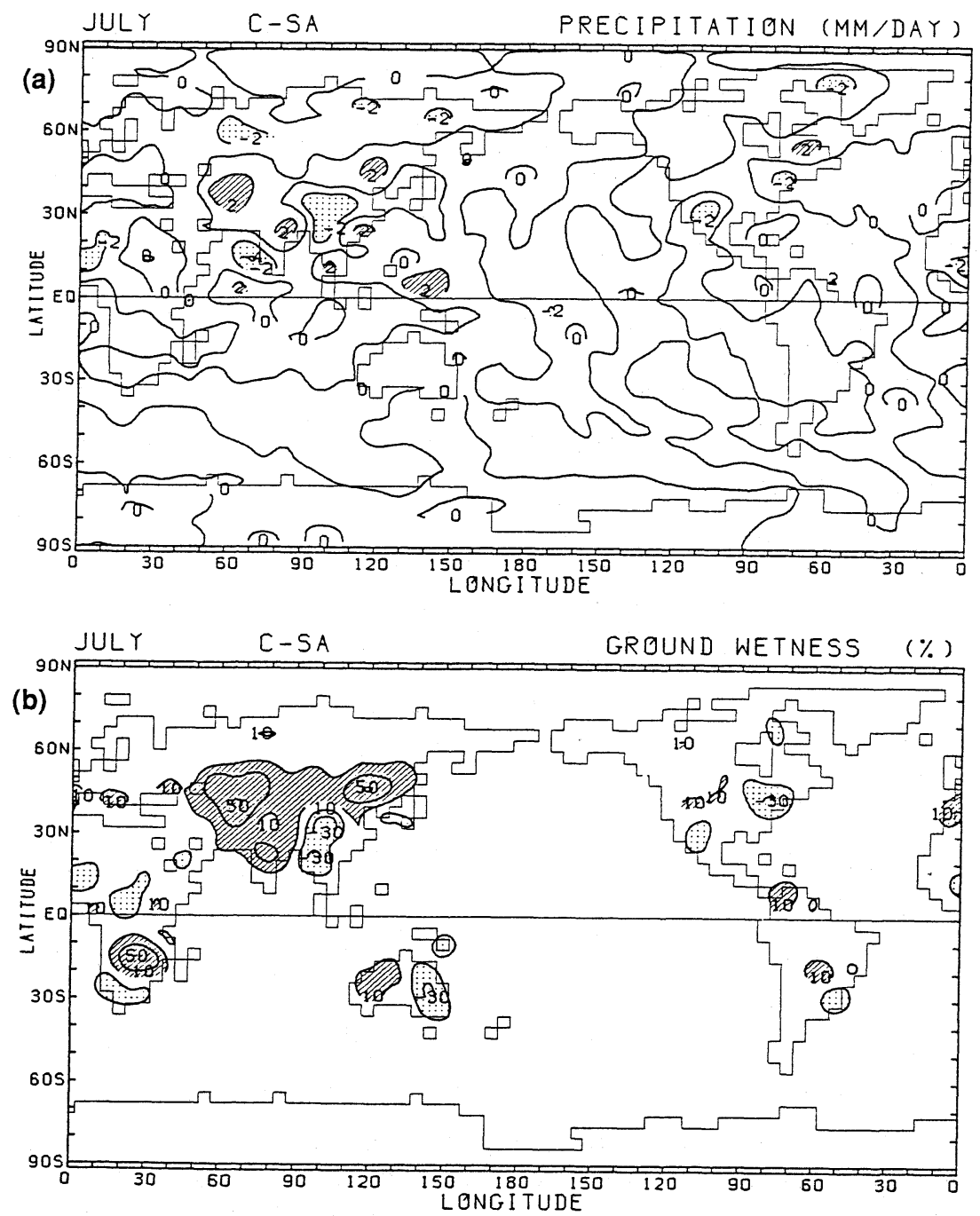

Fig. 23. Same as in Fig. 5 except for between the $\mathrm{C}$ run and the SA run and for July. 

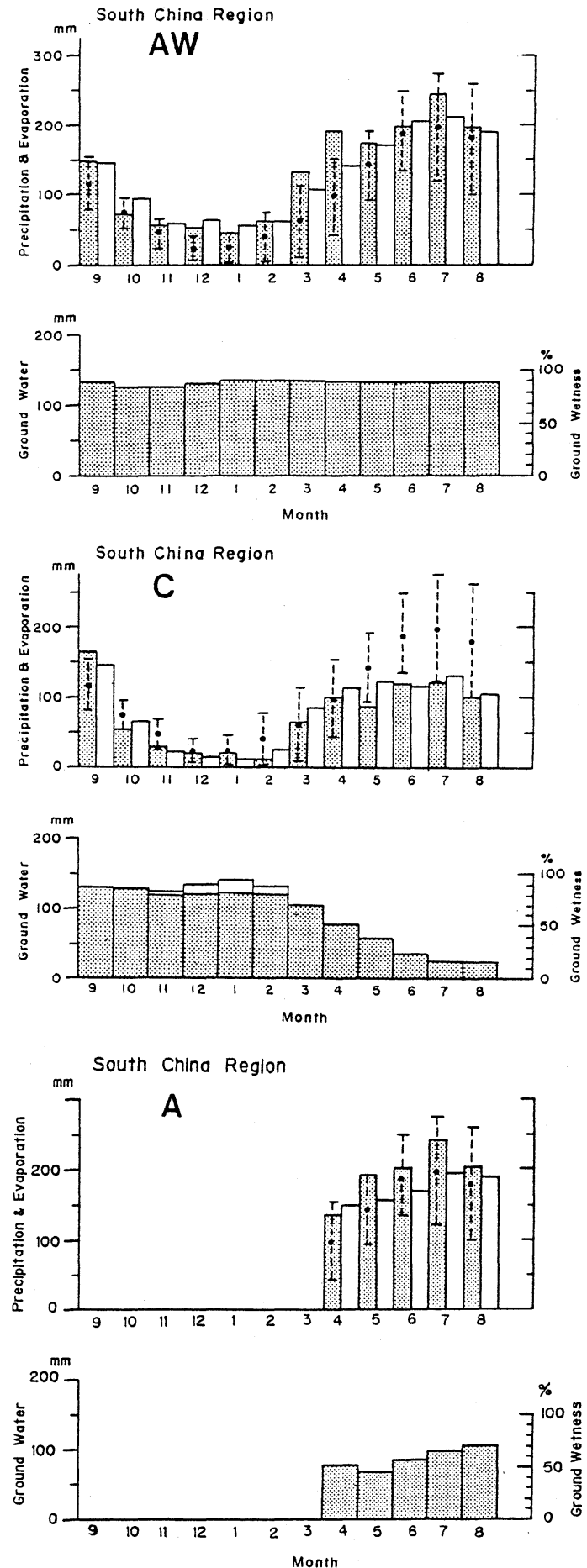

Fig. 24. Seasonal variation of monthly precipitation (stippled column at the upper panel), evaporation (white column at the upper panel), ground moisture (stippled column at the lower panel) and snow mass (white column at the lower panel) at south China region $\left(24^{\circ} \mathrm{N}-32^{\circ} \mathrm{N}, 97.5^{\circ} \mathrm{E}-\right.$ $117.5^{\circ} \mathrm{E}$ ) for the AW run (top two panels), the $\mathrm{C}$ run (middle two panels) and the $\mathrm{A}$ run (bottom two panels). Closed circles with error bars denote observed monthly precipitation amounts (see text in detail).
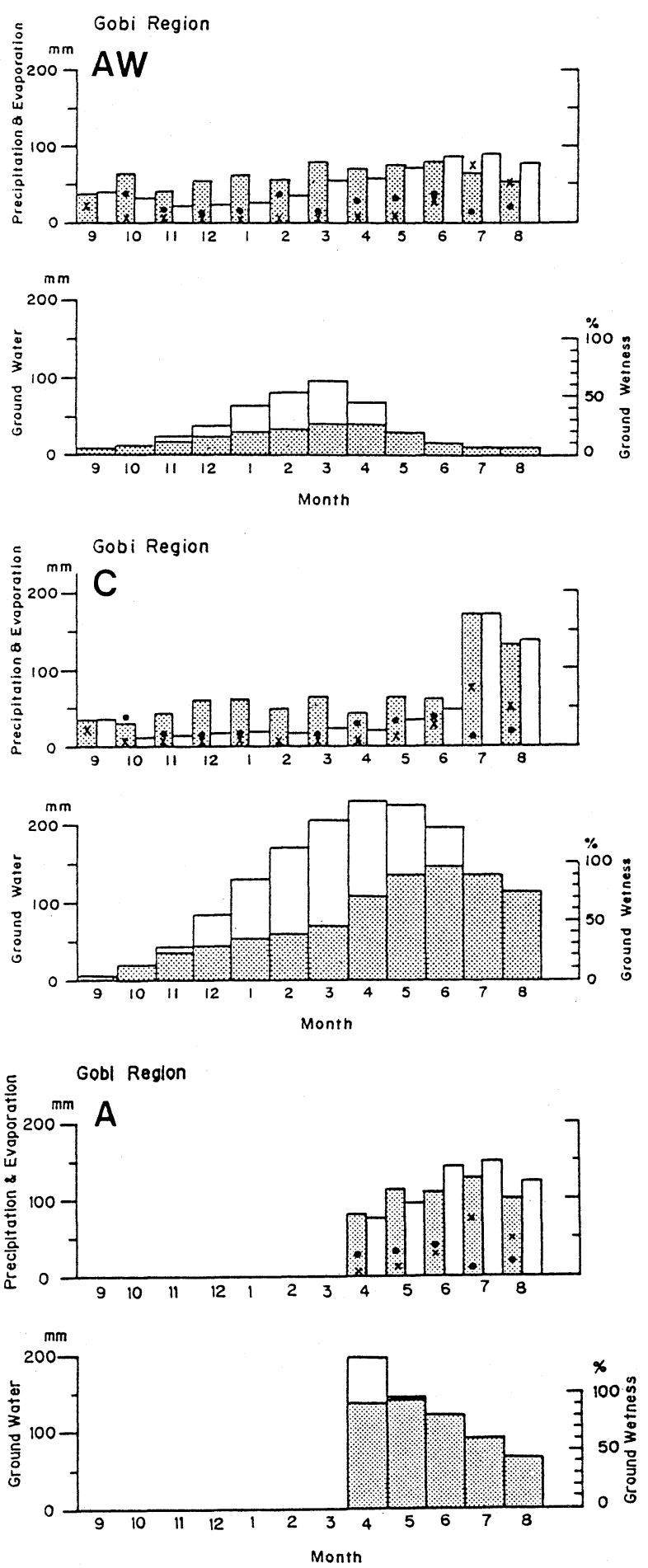

Fig. 25. Same as in Fig. 24 except for Gobi Desert region $\left(40^{\circ} \mathrm{N}-48^{\circ} \mathrm{N}, 87.5^{\circ} \mathrm{E}-\right.$ $\left.107.5^{\circ} \mathrm{E}\right)$. Closed circles denote observed monthly precipitation amounts at Ulan Bator $\left(48^{\circ} \mathrm{N}, 107^{\circ} \mathrm{E}\right)$ and crosses denote those at Urumqi $\left(44^{\circ} \mathrm{N}, 88^{\circ} \mathrm{E}\right)$. 

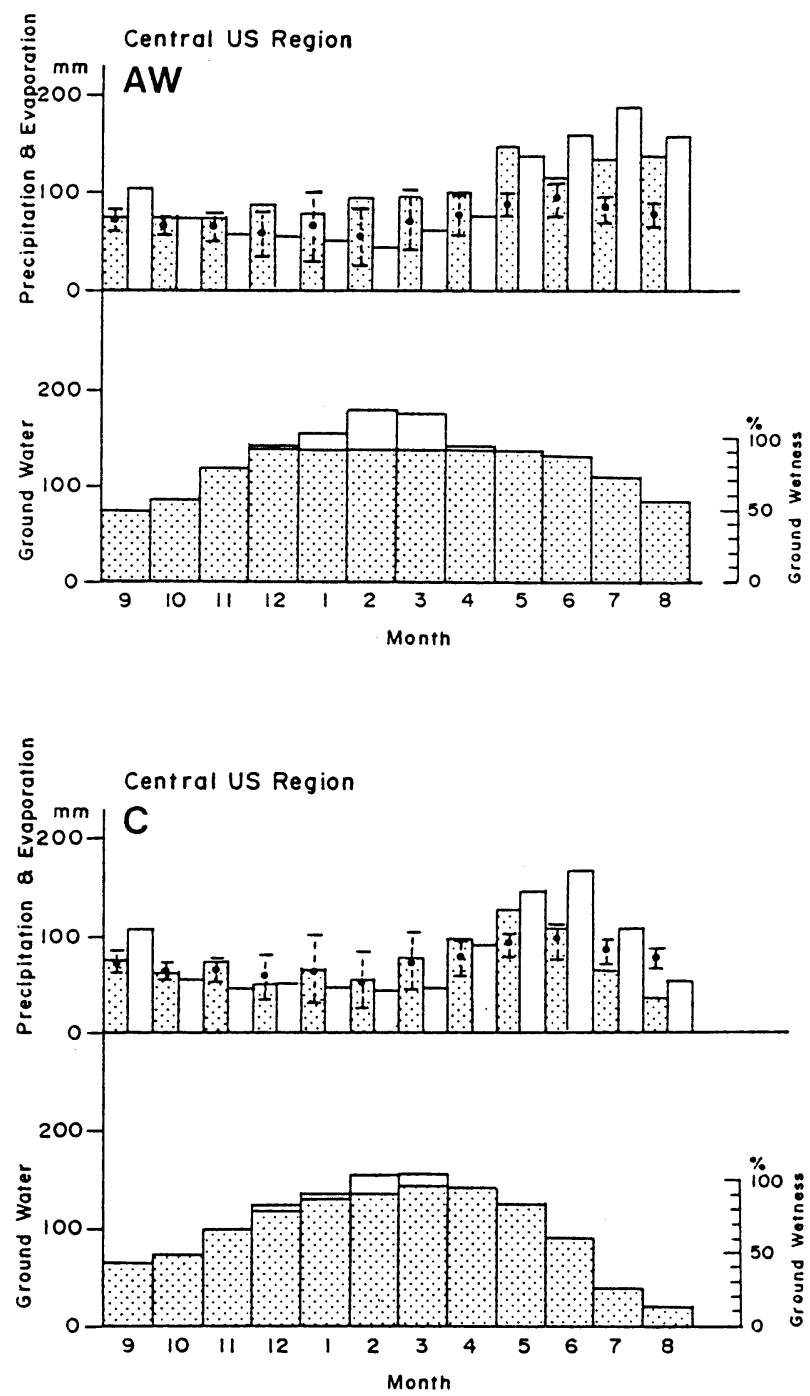

Fig. 26. Same as in Fig. 24 except for central U.S. region $\left(36^{\circ} \mathrm{N}-48^{\circ} \mathrm{N}, 77.5^{\circ} \mathrm{W}-92.5^{\circ} \mathrm{W}\right)$. Figures for the $\mathrm{A}$ run are not included.

those at the south China region (see Figs. 2 and 14). Here the seasonal variation of precipitation is not large compared with the south China region. In both runs, precipitation is less than evaporation during summer and the moisture flux is divergent here, contrary to the south China region (see Fig. 16). In the $\mathrm{C}$ run, the ground wetness is less than $50 \%$ in July and August. Hence the evaporation and precipitation decrease rapidly from June to August. It is noticed that the large difference between the $\mathrm{C}$ run and the AW run comes from the difference in ground wetness.

\subsection{Amazon region}

Figure 27 shows monthly precipitation, evaporation and ground wetness over the Amazon region $\left(0^{\circ} \mathrm{S}-12^{\circ} \mathrm{S}, 42.5^{\circ} \mathrm{W}-67.5^{\circ} \mathrm{W} ; 15\right.$ grid points $)$. The region includes the tropical rain forest. The closed circles denote observed climatological mean monthly precipitation amounts averaged over 3 stations within the region (Manaus, $3^{\circ} \mathrm{S}, 60^{\circ} \mathrm{W}$; Belem,
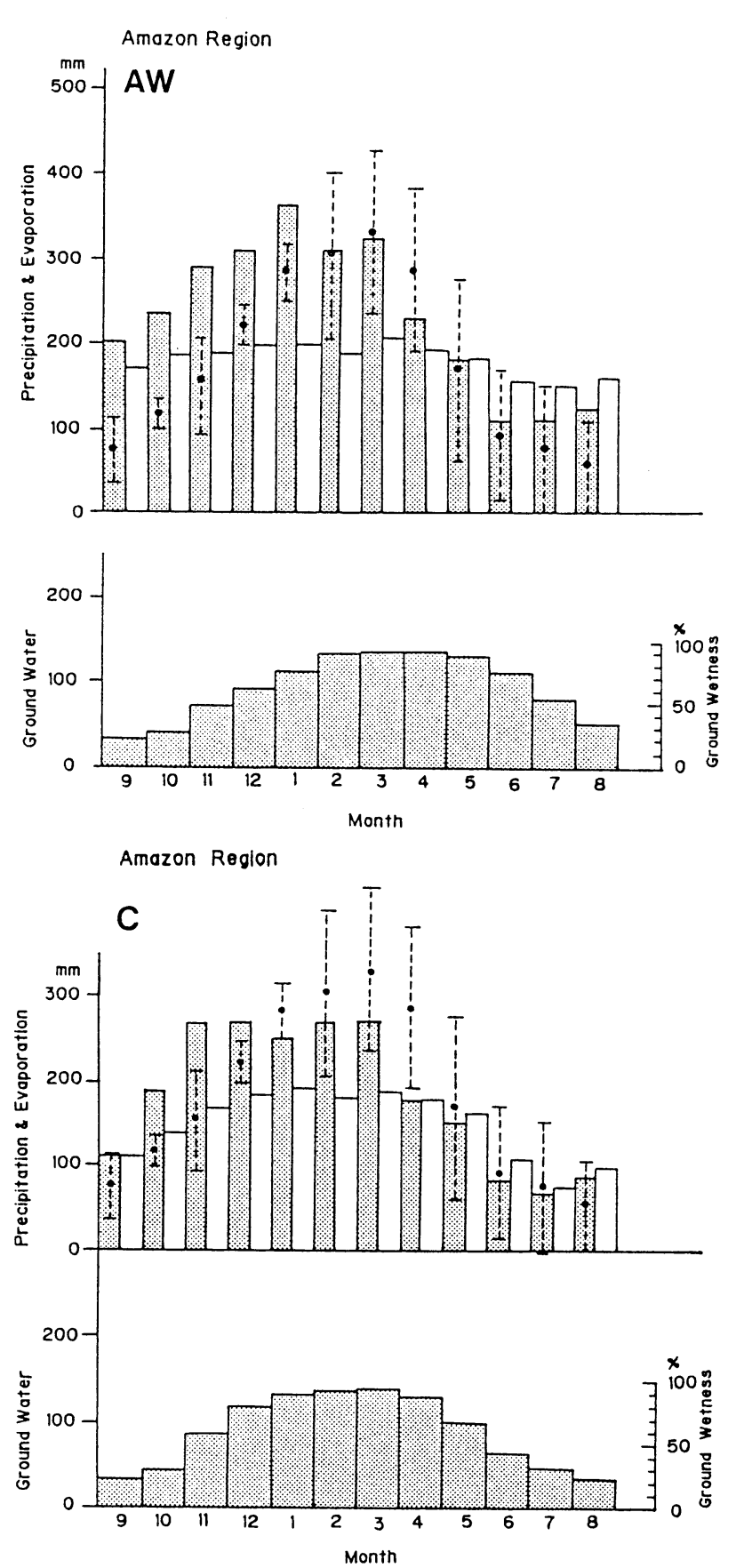

Fig. 27. Same as in Fig. 24 except for Amazon Region $\left(0^{\circ} \mathrm{S}-12^{\circ} \mathrm{S}, 42.5 \mathrm{~W}-67.5^{\circ} \mathrm{W}\right)$.

Figures for the A run are not included.

$1^{\circ} \mathrm{S}, 48^{\circ} \mathrm{W}$; Conceicao de Araguaia, $8^{\circ} \mathrm{S}, 49^{\circ} \mathrm{W}$ ). The error bars denote the standard deviations among 3 stations.

The difference between the $\mathrm{C}$ run and the $\mathrm{AW}$ run is not so pronounced in this region. In fact, the difference is not statistically significant in July (Fig. A2). The predicted ground wetness in the $\mathrm{C}$ run undergoes large annual variation and it seems reasonable. Unlike other regions, the ground wetness in August in the $\mathrm{C}$ run is close to that in the previous September. Both runs seem to overestimate precip- 


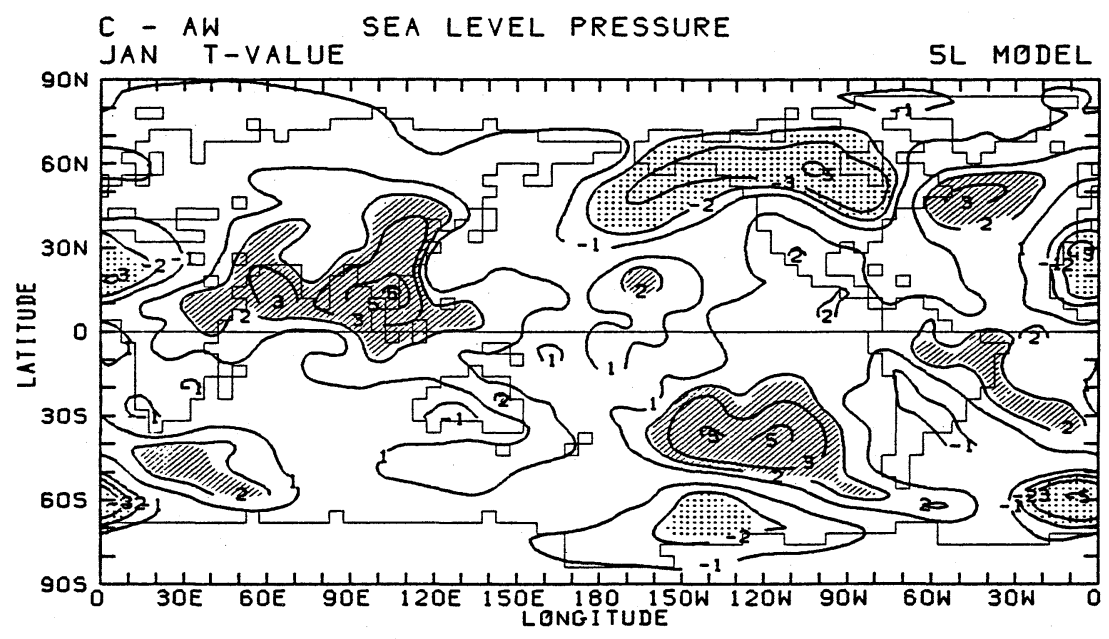

Fig. A1. t-values for sea level pressure difference, C-AW, in January. The contour interval is 1 . Zero contours are not drawn. Values greater than 2.2 (significant at $5 \%$ level) are hatched and those less than -2.2 are stippled.

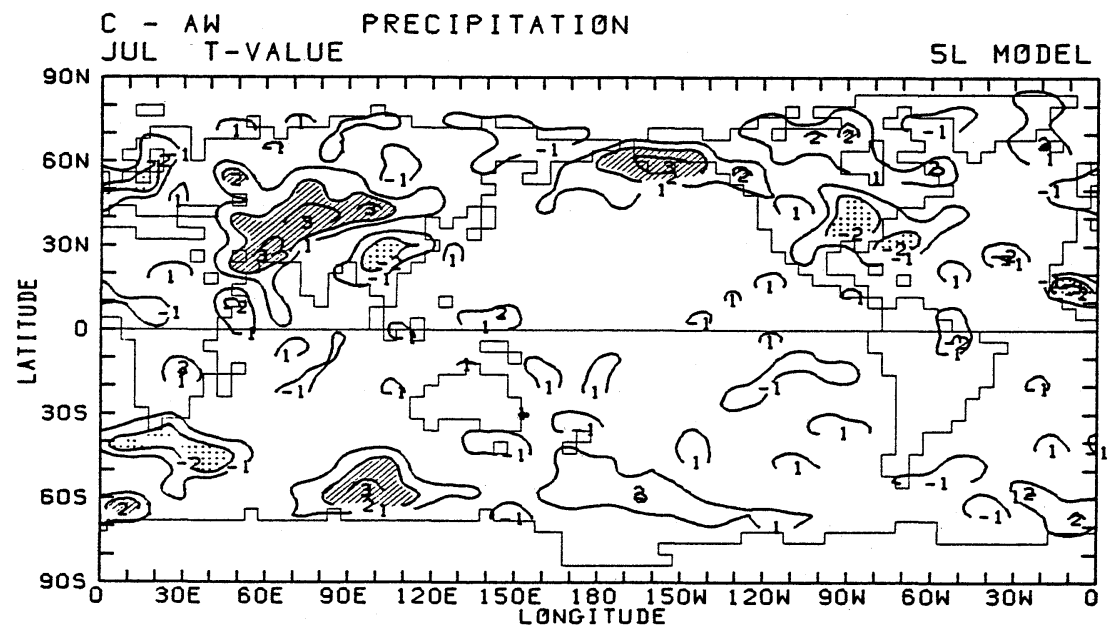

Fig. A2. Same as in Fig. A1 except for precipitation difference in July.

itation for the period from September to December. The precipitation is much larger than the evaporation during the period from October to March in both runs. During the dry season (May to August), the evaporation is larger than the precipitation.

\section{Summary and discussion}

In arid regions such as Sahara, where the albedo differences between the $\mathrm{C}$ run and the $\mathrm{AW}$ run are large, the "albedo feedback" of bare land is important. In this respect, the present results accord with the results in Charney et al. (1977), Sud and Fennessy (1982), Yamazaki (1986) and Kitoh et al. (1988). These results support the idea that high albedo over deserts helps to maintain dry conditions there.

In this paper, the importance of snow albedo in influencing summer climate has been pointed out.
Various surface albedo data are currently used in GCMs. A comprehensive review on this subject is found in Henderson-Sellers and Wilson (1983). For snow-covered surfaces, the surface albedo used in various models ranges from 0.5 to 0.85 . In some models, it depends on its depth or age. The value adopted in the standard MRI.GCM-I, i.e., 0.7-0.85 is the highest and it seems to be representative for snow in the Arctic and Antarctic (e.g., Yamanouchi, 1983). However, it seems to be too high in middle latitudes where trees or rocks are exposed and the grid-scale land is not fully covered by snow. The more accurate albedo data for snow and the better diagnostic scheme of the surface albedo will be needed because snow albedo is a crucial factor which controls the climate in the Northern Hemisphere as shown in this paper.

Yeh et al. (1983) studies the effect of a large-scale 
removal of snow cover in middle and high latitudes during the early spring season using a simplified general circulation model with a limited computational domain and idealized geography. They find that removal of snow cover reduces the water available to soil through snowmelt and negative anomaly of soil moisture in this region persists for the entire spring and summer. Our A run, in which snow melts earlier compared with $\mathrm{C}$ run owing to the reduced snow albedo, is somewhat similar to their experiment, though artificial removal of snow cover is not made in our case. In our case, negative anomaly of soil moisture develops (not persist) during late spring and summer in middle latitudes. In high latitudes the anomaly is small. In subtropical latitudes, their results show no significant anomaly. In our case, however, the negative anomaly appears in Southwest Asia and the positive one appears in Southeast Asia, though the zonal mean over Asia is small. This fact shows the importance of including realistic geography and also shows the possibility that snow cover in winter and spring over Eurasia affects the Asian monsoon activity in the subsequent summer. The present study supports the relationship beyween the Eurasian snow cover and the summer monsoon activity (Hahn and Shukla, 1976). To further study the snow-monsoon (and possibly -ENSO) interaction, a different sensitivity experiment on the initial snow cover will be needed. Such a study is in preparation at the MRI.

We summarize the results obtained from the numerical experiment on the sensitivity of the simulated climate to surface albedo and ground wetness as follows:

- In winter, the atmospheric circulation in the Northern Hemisphere is very sensitive to the surface albedo specification. Too strong a snowalbedo feedback makes the Siberian high strong and it makes the Aleutian low deep.

- After the snowmelt, the ground starts to dry and warm over most of Eurasia where moisture flux is divergent. The timing of snowmelt in spring affects the ground conditions in summer. If snow melts earlier, land becomes dry and warm and precipitation is less in summer over most of the Eurasian continent. In the southeast Asia summer monsoon region in the model ( moisture flux convergent region), however, the stronger moisture flux convergence due to a deeper low over the continent brings about more precipitation there and the ground wetness increases toward summer. Thus during summer greater precipitation is simulated when snow melts earlier. The speed of the snowmelt is controlled by snow albedo in this experiment.

- Surface albedo of bare soil has a significant ef- fect, particularly in low latitudes. High albedo produces less precipitation and low albedo produces much precipitation.

The MRI.GCMI-I has many deficiencies such as excessive rainfall in the tropics and over the summer continent, excessive snow cover in spring, a weak summer Asian monsoon, strong winter Asian monsoon, the lack of a 30-60 day oscillation in the tropics, and so on. As shown in this paper, some of these deficiencies are improved when the surface albedo and ground wetness are prescribed as the climatological values or when snow albedo is reduced. The 30-60 day oscillation can be generated by a modification of Arakawa-Schubert cumulus model (Tokioka et al., 1988). Still, the excessive rainfall in the tropics is not corrected by the modification of the cumulus model. The current results may depend on the model. Further improvement of the model is needed.

\section{Acknowledgments}

The author thanks Dr. T. Tokioka for his continuous encouragement and useful discussions and comments. He also expresses his thanks to $\mathrm{Mr}$. A. Kitoh for many useful comments on the original manuscript and for providing the figure of observed snow cover extent. Thanks are extended to Ms. H. Imai and Ms. H. Kimura for drafting figures. Computations were made with HITAC S810/10 at MRI.

\section{Appendix}

\section{Statistical significance}

Each run in this paper is only one realization. Therefore it is not possible to determine its statistical significance in an exact sense. However, in this appendix, approximate estimates are gained for the statistical significance of the difference between the $\mathrm{C}$ run and the AW run using the statistics of the 12-year simulation of the model (Tokioka et al., 1986). Here, we assume the standard deviations of the monthly mean fields in each run is equal to those in 12-year simulation. Then the Students' t-test is applied for C-AW.

Figure A1 shows the horizontal distribution of the estimated $t$-values for the sea level pressure difference between the $\mathrm{C}$ run and the AW run in January. The values greater than 2.2 , which correspond to the significant level at $5 \%$, are shaded and those less than -2.2 are dotted. Positive anomalies east and south of the Tibetan Plateau are highly significant. Negative anomalies over the Northeast Pacific and Canada are also significant.

Figure A2 shows the estimated t-values for precipitation difference in July. In Fig. A2, t-values for region where the 12-year averaged precipitation in July is less than $1 \mathrm{~mm} /$ day is set to zero to eliminate large $t$-values where the average precipitation 
is extremely small. Positive anomalies over central and southwestern Asia are highly significant. Negative anomalies over south China and central U.S. are significant. Anomalies in the tropics are not significant except over west Africa.

\section{References}

Arakawa, A. and W. H. Schubert, 1974: Interaction of a cumulus cloud ensemble with the large-scale environment. Part I. J. Atmos. Sci., 31, 674-701.

Barnett, T. P., L. Dümenil, U. Schlese and E. Roeckner, 1988: The effect of Eurasian snow cover on global climate. Science, 239, 504-507.

Charney, J. G., 1975: Dynamics of deserts and drought in the Sahel. Quart. J. R. Met. Soc., 101, 193-202.

Charney, J. G., W. J. Quirk, S. H. Chow and J. Kornfield, 1977: A comparative study of the effects of albedo change on drought in semi-arid regions. $J$. Atmos. Sci., 34, 1366-1385.

Hahn, D. J. and J. Shukla, 1976: An apparent relationship between Eurasian snow cover and Indian monsoon rainfall, J. Atmos. Sci., 33, 2461-2462.

Henderson-Sellers, A. and M. F. Wilson, 1983: Surface albedo data for climatic modeling. Rev. Geophys. Space Phys., 21, 1743-1777.

Katayama, A., 1972: A simplified scheme for computing radiative transfer in the troposphere. Tech. Report No. 6, Department of Meteorology, Univ. of Calif., Los Angeles, 77pp.

Katayama, A., 1978: Parameterization of planetary boundary layer in atmospheric general circulation models. Kisyo Kenkyu Note, Meteor. Soc. Japan, No. 134, 153-200. (in Japanese)

Kitoh, A. and T. Tokioka, 1986: A simulation of the tropospheric general circulation with the MRI atmospheric general circulation model. Part II: The July performance. Pap. Met. Geophys., 37, 145168.

Kitoh, A., K. Yamazaki and T. Tokioka, 1988: Influence of soil moisture and surface albedo changes over the African tropical rain forest on summer climate investigated with the MRI.GCM-I. J. Meteor. Soc. Japan, 66, 65-86.

Laval, K and L. Picon, 1986: Effect of a change of the surface albedo of the Sahel on climate. J. Atmos. Sci., 43, 2418-2429.

Mintz, Y., 1984: The sensitivity of numerically simulated climates to land-surface boundary conditions. The Global Climate, J. T. Houghton (ed.), Cambridge Univ. Press, 79-105.

Mintz, Y. and Y. Serafini, 1984: Global fields of monthly normal soil moisture as derived from observed precipitation and an estimated evapotranspiration. Final Scientific Report under NASA Grant No. NAS 5-26, Part V, Department of Meteorology, University of Maryland, College Park, Maryland.

Posey, J. W. and P. F. Clapp, 1964: Global distribution of normal surface albedo. Geofis. Int., 4, 33-48.

Randall, D. A., 1976: The interaction of the planetary boundary layer with large-scale circulations. Ph.D. Thesis. Univ. of Calif., Los Angeles, 247pp.
Rind, D., 1984: The influence of vegetation on the hydrologic cycle in a general circulation model. Geophysical Monograph, 29, American Geophysical Union, 73-91.

Shukla, J. and Y. Mintz, 1982: The influence of land surface evapotranspiration on Earth's climate. Science, 215, 1498-1501.

Sud, Y. C. and M. Fennessy, 1982: A study of the influence of surface albedo on July circulation in semiarid regions using the GLAS GCM. J. Climatology, 2, 105-125.

Sud, Y. C. and M. Fennessy, 1984: Influence of evaporation in semi-arid regions on the July circulation: A numerical study. J. Climatology, 4, 383-398.

Sud, Y. C. and W. E. Smith, 1985a: The influence of surface roughness of deserts on the July circulation -a numerical study. Bound. Layer Meteor., 33, $1-35$.

Sud, Y. C. and W. E. Smith, 1985b: Influence of local land-surface processes on the Indian monsoon: A numerical study. J. Climate Appl. Meteor., 24, 1015-1036.

Sud, Y. C. and A. Molod, 1988: A GCM simulation study of the influence of Saharan evapotranspiration and surface-albedo anomalies on July circulation and rainfall. Mon. Wea. Rev., 116, 2388-2400.

Sud, Y. C., J. Shukla and Y. Mintz, 1988: Influence of land surface roughness on atmospheric circulation and precipitation: A sensitivity study with a general circulation model. J. Appl. Meteor. (in press).

Tokioka, T., K. Yamazaki, I. Yagai and A. Kitoh, 1984: A description of the Meteorolocal Research Institute atmospheric general circulation model (the MRI.GCM-I).Tech. Reports of the MRI. No. 13, 249pp.

Tokioka, T., A. Kitoh, I. Yagai and K. Yamazaki, 1985: A simulation of the tropospheric general circulation with the MRI atmospheric general circulation model. Part I: The January performance. J. Meteor. Soc. Japan, 63, 749-778.

Tokioka, T., K. Yamazaki and A. Kitoh, 1986: Mean statistics of the tropospheric MRI.GCM-I based on 12-year integration. Tech. Reports of the MRI. No. 20,314pp.

Tokioka, T., K. Yamazaki, A. Kitoh and T. Ose, 1988: The equatorial 30-60 day oscillation and the Arakawa-Schubert penetrative cumulus parameterization. (J. Meteor. Soc. Japan, 66, 883-901).

Walker, J. and P. R. Rowntree, 1977: The effect of soil moisture on circulation and rainfall in a tropical model. Quart. J. R. Met. Soc., 103, 29-46.

Wilson, M. F., 1984: The construction and use of land surface information in a general circulation model. Ph.D. thesis, University of Liverpool, U.K., 346pp.

Yagai, I. and T. Tokioka, 1987: The effect of increased surface drag coefficient over the continents on January circulations. Short- and Medium-Range Numerical Weather Prediction. Collection of Papers Presented at the WMO/IUGG NWP Symposium Tokyo, 4-8 August 1986, Meteor. Soc. Japan, 409419.

Yamanouchi, T., 1983: Variation of incident solar flux 
and snow albedo on the solar zenith angle and cloud cover, at Mizuho Station, Antarctica, J. Meteor. Soc. Japan, 61, 879-893.

Yamazaki, K., 1986: The sensitivity experiment to land-surface boundary conditions with the MRI.GCM. Proc. ISLSCP Conference, Rome, Italy, 2-6 December 1985, ESA SP-248, 151-157.
Yeh, T.-C., R. T. Wetherrald and S. Manabe, 1983: A model study of the short-term climatic and hydrologic effects of sudden snow-cover removal. Mon. Wea. Rev., 111, 1013-1024.

Yeh, T.-C., R. T. Wetherrald and S. Manabe, 1984: The effect of soil moisture on the short-term climate and hydrology change - A numerical experiment. Mon. Wea. Rev., 112, 474-490.

\title{
土壤水分及び地表面アルベドの変化が気候に及ぼす影響の研究 一MRI GCM による数值実験—
}

\author{
山 崎 孝 治
}

(気象研究所・気候研究部)

土壌水分と地表面了ルベドの変化が気候に及ぼす影響について気象研究所大気大循環モデル（MRI ・ GCM-I）を用いて調ベた。コントロール・ラン（Cラン）は 9 月 1 日から 1 年間積分した。地表面水文 過程は標準的なバケツモデルで陸地上で一定の可能最大含水量 $15 \mathrm{~g} . \mathrm{cm}^{-2}$ 与えた。雪に覆われていない陸 地上の地表面アルベドは 0.14 の一定值とし、積雪がある場合はその地点の海抜高度に応じて 0.7 から 0.85 まで変化するとしている。アルベドと土壊水分を変えた 2 番目のラン（AWラン）も Cランとおなじ初期 条件から 1 年間積分した。AW ランでは、地表面アルベドと土壌水分量は気候值を与えた。したがって雪 とアルベドのフィードバックはなく、また、土㙵水分量は予報しない。アルベドの効果と土壌水分の効果 を分離するためにアルベドだけを気候值にしたランも行った。さらに雪のアルベドの効果だけを見るため に、雪のアルベドを $0.5 \sim 0.7$ に下げたランも行った。冬季北半球の大循環は地表面アルベドの与え方に非 常に敏感である。C ランでは AW ランに比べてシベリア高気圧は強く、かつ南東に張り出している。てれ はCランの雪とアルベドのフィードバックのためで、Cランでは中国南部まで雪が降っている。Cランで はアリューシャン低気圧は深く東偏し、北米に入り込み、逆にアイスランド低気圧は弱くなっている。夏 期の北半球の気候にとって雪のアルベドは非常に重要である。雪のアルベドが低いと、ユーラシア大陸の 乾燥地帯では、春の雪解けが早く起とり、夏にかけて、土壌が乾燥し、暖まる。その結果、そこでは夏の 降水量が減少する。逆に、中国南部地域では、夏に大陸が暖まるために水蒸気収束が強化され、夏の降水 量は増大する。降水量の増大は、土堹水分を増加させ、それがまた降水量を增加させる。つまり、雪のア ルベドは大気と地表面水文過程の相互作用を通じ夏の気候に大をく影響する。

雪に覆われていない地表面のアルベドも気候に影響を与える。特に低緯度で影響が大きい。アルベドが 高い（低ら）と、降水量は減少（增大）する。 